\title{
Botanical Pharmacognosy of Centella asiatica (Linn.)Urban
}

\author{
Madathilparambil Vasu Sudhakaran*
}

\section{Madathilparambil Vasu Sudhakaran*}

Associate Professor UGC-Academic Staff College University of Calicut Calicut University P.O, Malappuram, INDIA.

\section{Correspondence}

Madathilparambil Vasu Sudhakaran, Associate Professor UGC-Academic Staff College University of Calicut Calicut University P.O, Malappuram, INDIA.

Phone number: 9447500125

E-mail: dr.sudhakaranvasu@yahoo.co.in

\section{History}

- Submission Date: 18-04-2017;

- Review completed: 03-05-2017

- Accepted Date: 08-05-2017.

DOI : 10.5530/pj.2017.4.88

Article Available online

http://www.phcogj.com/v9/i4

\section{Copyright}

(C) 2017 Phcog.Net. This is an openaccess article distributed under the terms of the Creative Commons Attribution 4.0 International license.

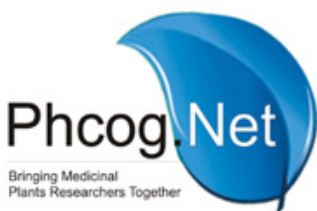

\begin{abstract}
Introduction: Centella asiatica (Linn.) Urban is an important medicinal plant with rejuvenate properties, used in Ayurveda for promoting vitality and life. The plant is often considered as a 'panacea' for several human ailments and the biological actions often has been ascribed to its pentacyclic triterpene compounds, mainly asiatic acid, madecassic acid and triterpene saponin-asiaticoside, madecassoside. The plant is also highly specialized for the richness of several micronutrients, iron, phosphorus, sodium, vitamin C, vitamin A, carotene and dietary fibers. Objectives: The present study was performed with the objectives of elaborating the macroscopic and histo-morpho diagnostic profile of Centella asiatica and to analyze the quantitative, and powder microscopic peculiarities to support its pharmacognostic characterization. Materials and Methods: Microscopic evaluation, quantitative standards and powder microscopy were carried out using the root, stolon, petiole and leaves. Results: Distribution of slightly lobed leaf margin with actinodromous major venation pattern, amphistomatic epidermis with animocytic stomata, distinctive contour of the midrib and petiole, occurrence of crystals in the idioblasts of the cortical parenchyma of root, stem, stolon, palisade and mesophyll. Vascular system with several free collateral bundles in the stem were features characteristic of the species. These findings in conjunction with reduction in lignified elements, arenchyma lacunae, sclerenchymatous netting in root, periphloematic sclereids in petiole, and stolon could be remarkable features diagnostic of the taxon. Conclusion: The present macroscopic and histo-anatomical observations of stem, root, stolon, petiole and leaves of Centella asiatica and powder microscopic, quantitative standards put forth could provide useful information for the regulatory aspects of the quality control measures of the crude drugs.
\end{abstract}

Key words: Animocytic stomata, arenchyma, periphloematic sclereids, calcium oxalate, crystal idioblasts.

\section{INTRODUCTION}

Centella asiatica (Linn.) Urban is a prostrate, faintly aromatic, stoloniferous, perennial, creeping runner belongs to the family Apiaceae (also known as Umbelliferae, this old-fashioned family name has been conserved under 'Nomina Conservanda' of the Rules of ICBN), is a tropical medicine native to Southeast Asian countries. The genus Centella, comprised about 40 species. ${ }^{1}$ The generic name Centella (ken-TEL-uh) is derived from the Greek centum-means hundred; referring to profusely branched prostrate runner and specific epithet asiatica (a-see-AT-ee-kuh) alludes to that it is native of the continent of Asia. This plant was originally described and published under the name Hydrocotyle asiatica by Carl Linnacus until it was reclassified as in the valid botanical systematics of Centella asiatica (Linn.) Urban. The reniform or fan shaped lamina with shallow crenate margin are about the size of an old British penny - hence its common name Indian pennywort, and also water pennywort or marsh pennywort because of the preferred natural habitat. Since the plant is of pan-tropical distribution, it is known by an array of vernacular names in different regions of the world as; Fo-titieng (in Chinese); indischer Wassernabel (in German); tsubo-kusa (in Japanese); hydrocotyle asiatique (in French); idro- cotile (in Italian); hierba de clavo (in Spanish) and gotukola in English ('gotukola' is originated from Sinhala language of Sri Lanka), pegaga (in Malaysia), daunkaki kuda (in Indonesia) and Brahmamanduki or Mandukaparni in Sanskrit. The species is native to India, China, Pakistan, Sri Lanka, Indonesia, Malaysia, and South Africa and found throughout the warmer, marshy to wet sandy areas on floodplains, and near streams, rivers or other watercourses.

Centella asiatica (Linn.) Urban has been used as a medicine in India since ancient time and as a rasayana (adaptogenic) drug for enhancing cognitive function by revitalizing the nerve and brain cells and hence the popularly known as Brahmi (or the brain food or memory enhancer). The plant had mentioned and described as Mandukaparni in classical Ayurveda treatise, Susruta Sanhita ${ }^{2}$.The plant has also been used extensively as a traditional remedy for a wide spectrum of ailments such as leprosy, psoriasis, eczema, dermatitis, ulcerous skin, wound burn, scar management and as adaptogenic and cardiotonic agents. Most of the biological actions of Centella asiatica have been ascribed to the pentacyclic triterpene compounds mainly asiatic acid, madecassic acid and triterpene saponin-asiaticoside, madecassoside. ${ }^{3}$ Mandukaparni is also a good source for several micronutrients, iron, phosphorus,

Cite this article : Sudhakaran MV. Botanical Pharmacognosy of Centella asiatica (Linn.)Urban. Pharmacog J. 2017;9(4):546-58. 
sodium, vitamin $\mathrm{C}$, vitamin $\mathrm{A}$, carotene and dietary fibres. ${ }^{3}$ This ancient Asian herbal remedy is now becoming popular in theWest ${ }^{4}$.

Centella asiatica (Linn.) Urban is often considered as a 'panacea ${ }^{25}$ for several ailments, hence the plant species have extensively been investigated by various workers for the phytochemical, ${ }^{6}$ pharmacological, ${ }^{7}$ microbiological ${ }^{8}$ and physiological ${ }^{9}$ studies. Data on many recent experimental studies have scientifically validated the traditional uses of the extract of Mandukaparni. These findings endorse that the plant having multiple therapeutic potentials, which were amply and vividly demonstrated by different animal models such as wound-healing model in rat, ${ }^{10-11}$ streptozocin-induced Alzheimeir's model ${ }^{12}$, zebrafish Parkinson's model ${ }^{13}$ adriamycin-induced cardiomyopathy model, ${ }^{14}$ nitroglycerine and bradykinin induced hyperalgesia (migraine) model, ${ }^{15}$ radiationinduced dermatitis model, memory impairment induced by cerebral ischemia-reperfusion ${ }^{16}$ and also having anxiolytic, ${ }^{17}$ neuronal dendritic growth and nerve stimulating effects, ${ }^{18}$ suppression of scars in diabetic patients, ${ }^{19}$ and reverse mutation assay for non-toxicity, safety and nonmutagenicity of the extract, ${ }^{20}$ protection of healthy cells against radiationinduced damages. ${ }^{21}$

However, the botanical standards specified for evaluation of intact plant material of Centella asiatica in literature ${ }^{22-25}$ seemed to be too scanty and not exhaustive enough to extricate the crude raw materials from the adulterants and substitutes. Therefore, the present study was undertaken with the objectives of elaborating the morphological and histological characteristics of the root, stem, stolon, lamina, and epidermal peel, mid vein, petioles and powder microscopy of the Centella asiatica using the techniques of digital, polarizing and stereo microscopy. It also aims to delineate and establish pharmacongostic markers which may reach some of the important target regarding the regulatory aspects of quality control measures, and fill the existing lacunae of the botanical pharmacognosy of Centella asiatica to a considerable extent.

\section{MATERIALS AND METHOD}

\section{Materials}

The plant is herbaceous, slender, prostrate, creeping runner and attains a height up to $12-15 \mathrm{~cm}$ (Figure $1 \& 1 \mathrm{a}$ ). Stem is reddish, glabrous (Figure 1c) with long slender, horizontal stolons. A cluster of ascending petiolate leaves arising at each node of the stem and portrays of having long internodal length (Figure 1b). Leaf; simple, lamina is rounded to reniform at the tip, petiole elongated, slightly pubescent on both surfaces. Stem with sheathing leaf bases consisted of 1-3 leaves at each node. Lamina is broadly cordate at the base, coarsely toothed, crenate margins. Petiole is dorsi-ventrally differentiated (Figure 1b); and ventral side appeared furrowed (Figure 1b). Inflorescences: fasicled umbel, each umbel consisted of three purple or pink flowers (Figure 1d), borne on long peduncle (1 to $1.5 \mathrm{~cm}$ ). Usually set $2-3$ flowers side by side on short pedicel (Figure 1e). The petals are five, pink colored and often tinged with rose; Fruit: cremocarp, having the dimension of 3 to $4 \mathrm{~mm}$ long and 3 to $5 \mathrm{~mm}$ broad (broader than long), ellipsoid in shape with thickened pericarp. Flowering occurs in the month of April-June.

\section{Methods}

In Kerala, the plant flourishes extensively in paddy fields, river banks and streams also form as the plants of garden edges, shady stone walls, rockeries and wet surfaces. Centella asiatica (Linn.) Urban. for the present study was collected from the Thiruvananthapuram District of the State of Kerala and identification and authentication were done using Gamble's Flora of Presidency of Madras. Fine hand sections of lamina, petiole, stem, root, stolon and epidermal peels were taken using standard procedures and stained with aqueous Safranin 1\% and mounted in glycerin. The investigation on macroscopic, micromorpho diagnostic

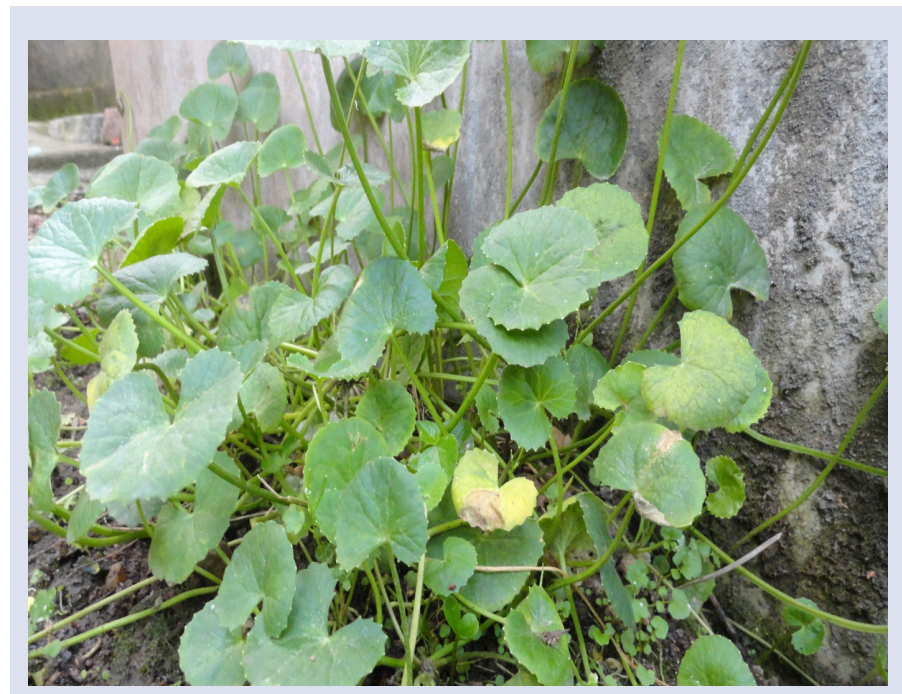

Figure 1: Centella asiatica (Linn.) Urban

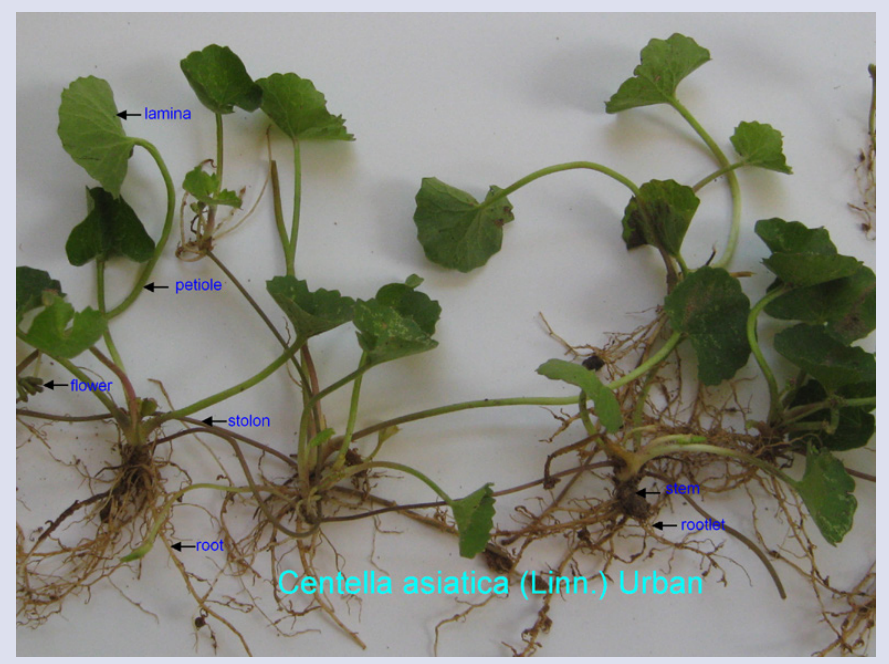

Figure 1a: Centella asiatica (Linn.) Urban

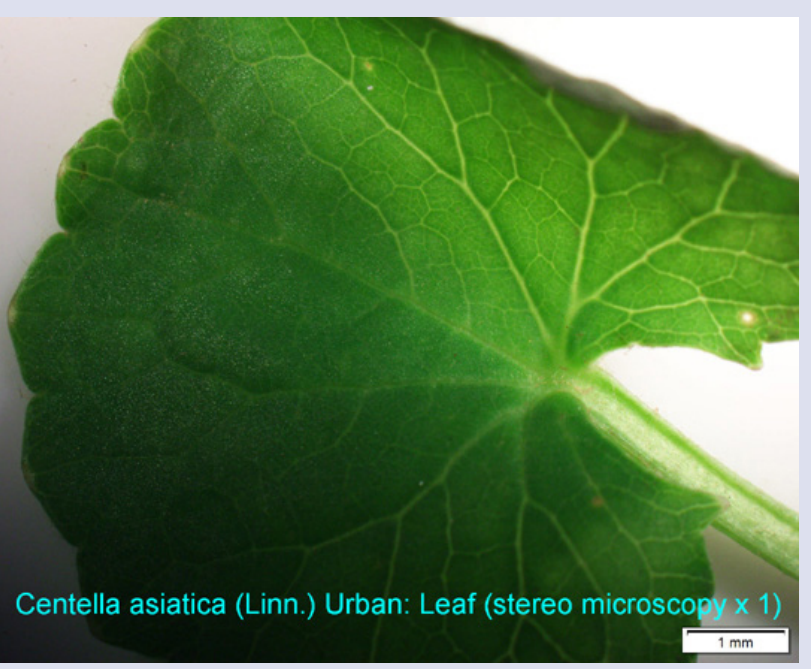

Figure 1b: Centella asiatica (Linn.) Urban: Leaf (stereo microscopic view x1) 


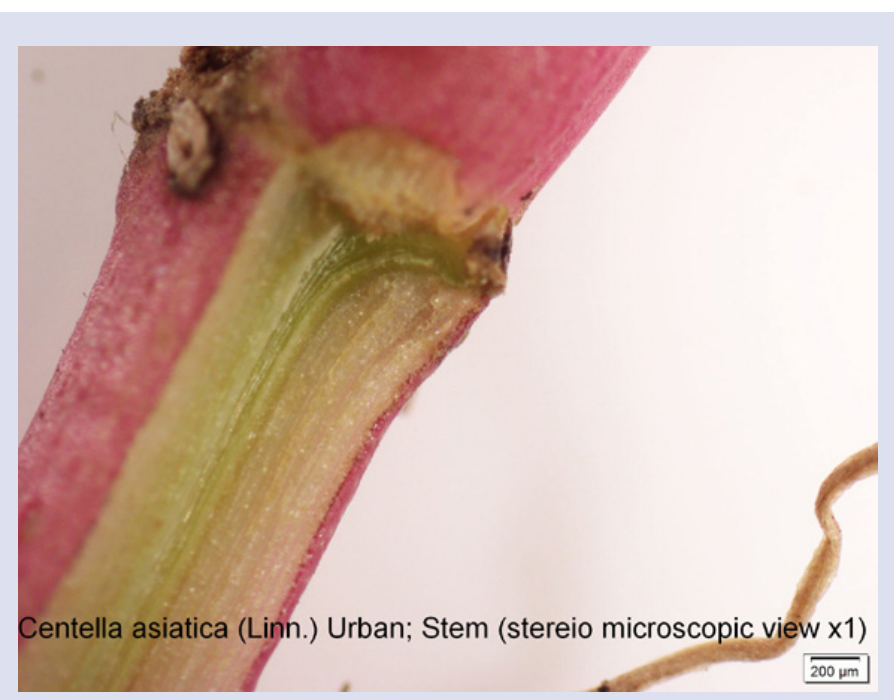

Figure 1c: Centella asiatica (Linn.) Urban: Stem (stereo microscopic view x1)

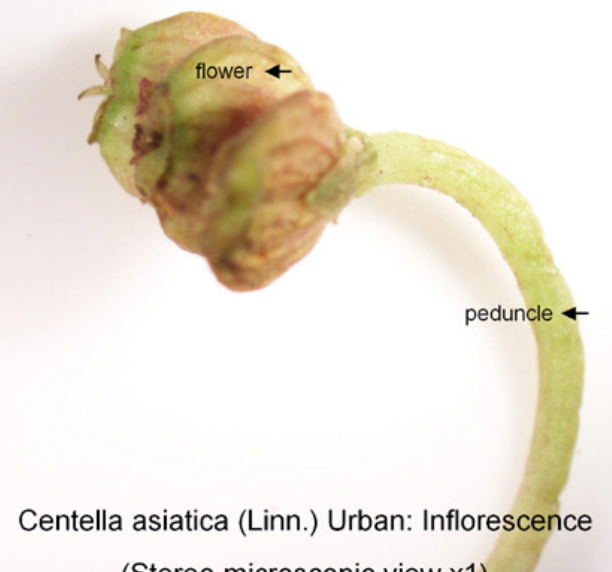

(Stereo microscopic view $\times 1$ )

$\overline{500 \mu \mathrm{m}}$

Figure $1 \mathrm{~d}$ : Centella asiatica (Linn.) Urban: Inflorescence (stereo microscopic view $\mathrm{x} 1$ )

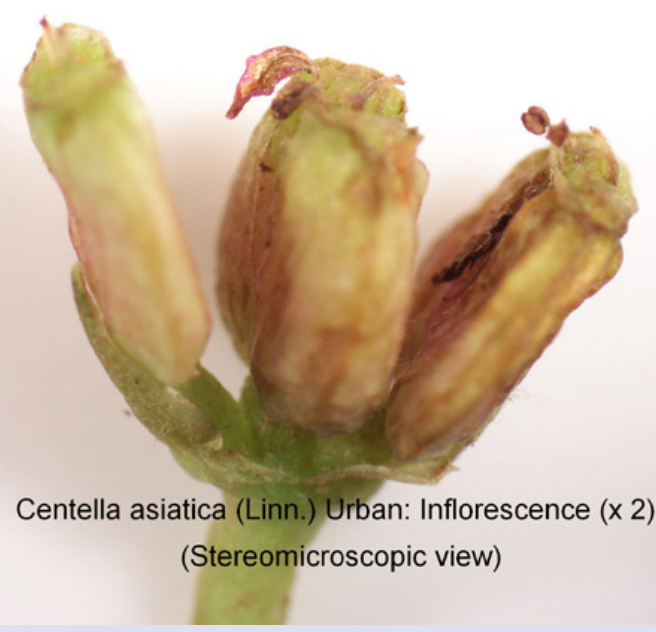

$\overline{200 \mu \mathrm{m}}$

Figure 1e: Centella asiatica (Linn.) Urban: Inflorescence (stereo microscopic view $\times 2$ ) profile, analysis of quantitative, and powder microscopic properties of the specimens were undertaken. Microphotographs of sections and powder analysis were made by using Olympus Microscope (Model CX 41; Tokyo, Japan) with CCD camera 2 mega pixel and quantitative measurements were taken using Olympus Image-Pro Plus, version 5.1 software. Palisade ratio was determined based on Wallis ${ }^{26}$ and size of Guard Cell Area (GCA) was estimated following Franco's formula. ${ }^{27}$ The descriptive terms of the anatomical features used here as per Hickey, ${ }^{28}$ Metcalfe and Chalk, ${ }^{29}$ and Sudhakaran. ${ }^{30-31}$

\section{RESULTS AND DISCUSSION}

\section{Microscopic evaluation of root}

The taproots are elongated, cylindrical, tapered towards the ends and brownish in color. T.S of the young root (Figure $2 \& 2 a$ ) appeared circular in outline with tissue organization as outer piliferous layer, followed by the middle cortex and inner stele (Figure $2 \& 2 \mathrm{~b}$ ). Outer 2-3 layers of young root consisted of soft, thin walled, rectangular or polygonal shaped parenchymatous cells with small intercellular spaces. Cells were mostly empty and appeared reddish to brown in color, but some cells contained the deposition of colored secretary substances. Cortex was very prominent and constituted the major portion of the root. Cortex appeared differentiated to two distinct zones; the outer and inner cortex. Cells of the outer cortex contained 3-5 prenchymatous cells with higher proportion of schizogeneously formed air chambers (arenchyma). The presence of arenchyma in the cortical region (Figure 2a), which facilitates the aeration of internal tissues of the root, under marshy environmental condition, which helps in gaseous exchange. This structural anatomy of the young root having a row of arenchyma lacunae around the outer cortical region, adapts the plant to thrive anaerobic condition of a hydrophytic environment in marshy/wet land places. The major portion of inner cortical region was enmeshed with a reticulate network of non-lignified or slightly lignified sclenchymatous net (Figure $2 c \& 2 d$ ). The presence and pattern of alignment of the sclenchymatous net across the cortical region enclosing the vascular elements of the root could be considered as a characteristic feature of the taxon. Some of the inner cortical parenchymatous cells were contained simple starch grains. The corners and between of the intervening walls of the outer cortical parenchyma cells were often embedded with prismatic crystals of calcium oxalate of various shapes and sizes. Stele constitute comparatively narrow zone, and xylem elements were highly reduced and represented largely by xylem vessels and the centre of root devoid of any sclerenchyma cells (Figure $2 \mathrm{~d} \& 2 \mathrm{e}$ ), but it appeared filled with parenchymatous ground tissue. Vessels were mostly solitary and small sized, majority of them were arranged in radial rows (Figure 2e). The mean diameter of xylem vessel lumen was $17.2 \mu \mathrm{m}$. The number of xylem vessels was very few in number and were polygonal in shape (Figure 2e) and inter vessel pits in alternate position (Figure 2f), with pit aperture having a mean diameter of about $4.5 \mu \mathrm{m}$ (Figure 2g). Medullary rays were broad, many cells wide and consisted of radially elongated, rectangular parenchymatous cells.

\section{Microscopic evaluation of stem}

T.S of the stem appeared irregularly circular in outline (Figure 3) with tissue organization as outer epidermis, followed by the middle cortex and inner stele. Epidermis consisted of uni-layered rectangular cells with thick cuticle. The Cortex was broad and wide; occupying several rows of cells. Some of the outer cortical cells contained prismatic crystals of calcium oxalate, the size of the crystals ranged from 13.8 to $31.5 \mu \mathrm{m}$ in diameter. The most remarkable feature of the inner cortex was the presence of patchy or banded deposition of secretary substances (Figure 3a \& 3c). Which appeared as yellowish- brown bodies (dimension of colored 


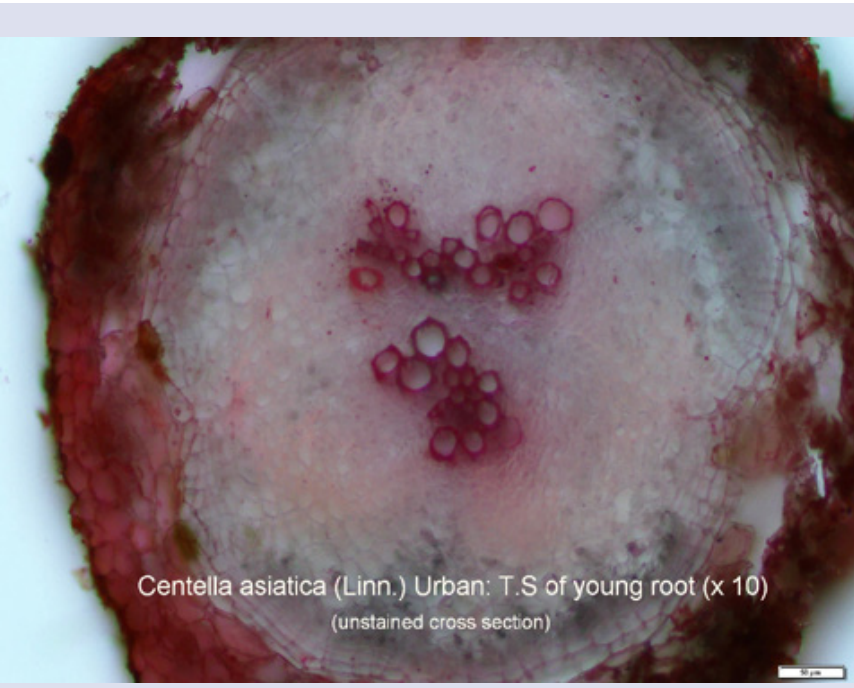

Figure 2: Centella asiatica (Linn.) Urban: T.S. of young root (unstained $\times 10$ )

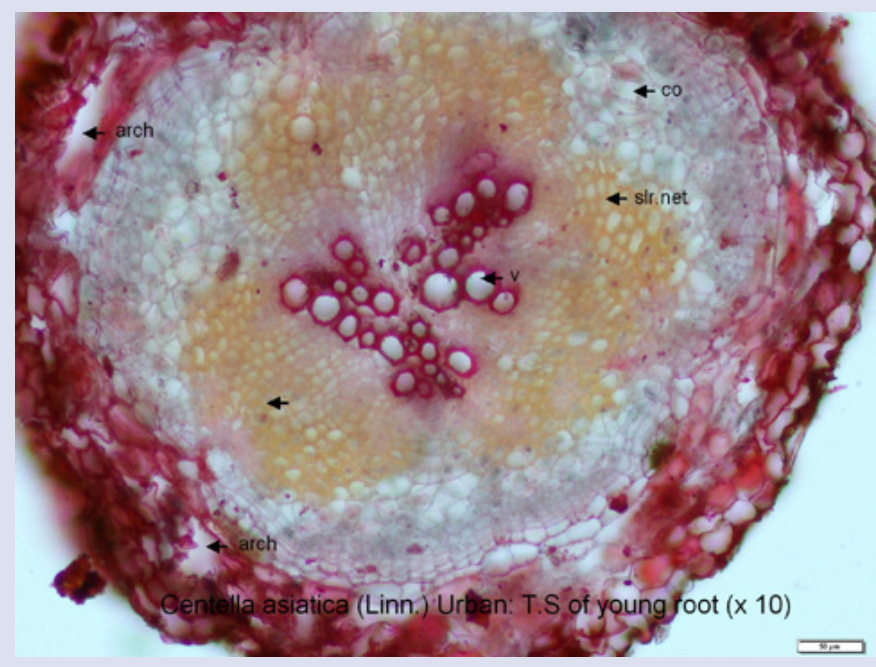

Figure 2a: Centella asiatica (Linn.) Urban: T.S. of young root $(\times 10)$

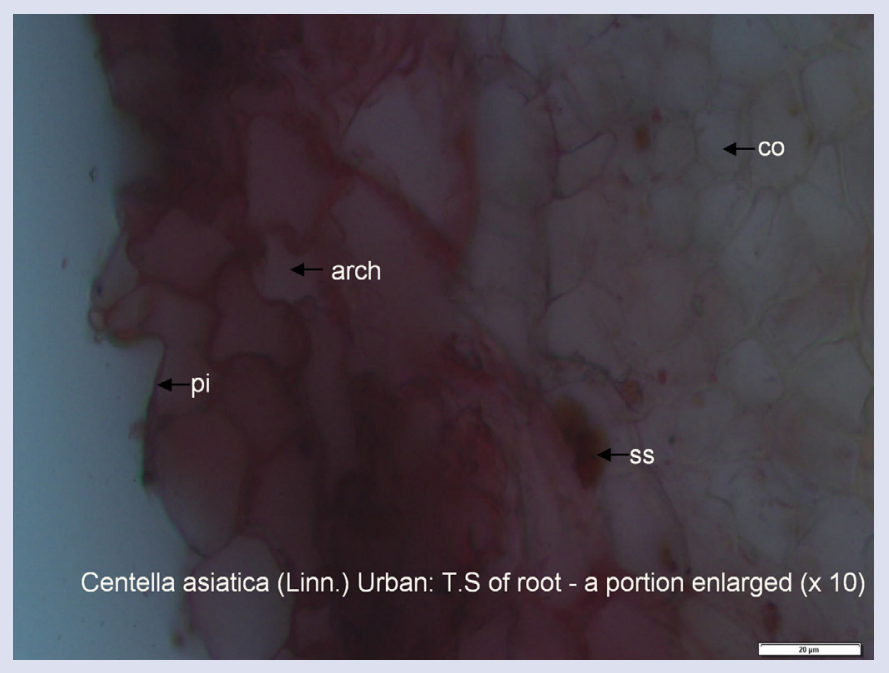

Figure 2b: C.asiatica (Linn.) Urban: T.S. of root - a portion enlarged (x 10)

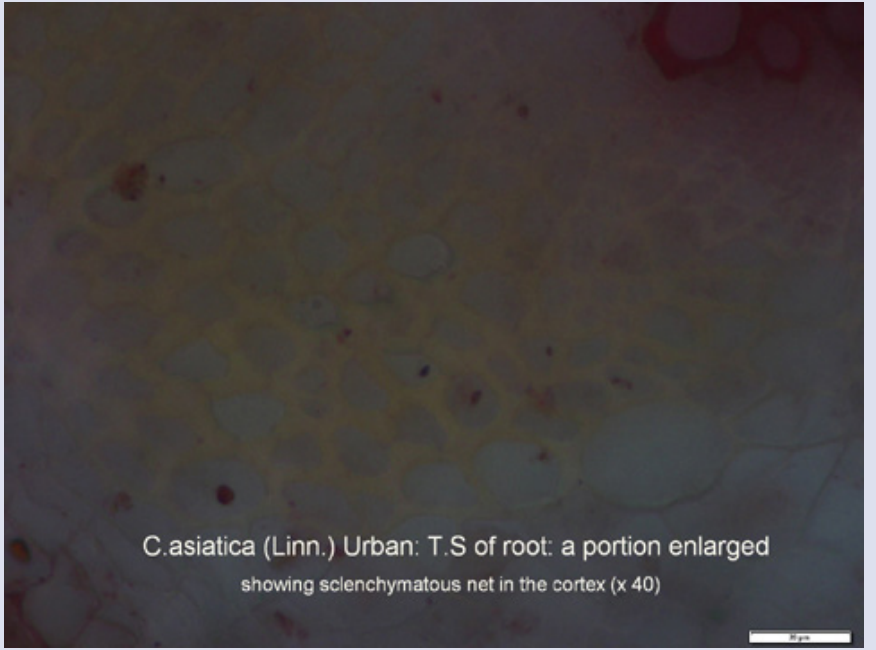

Figure 2c: C.asiatica (Linn.) Urban:T.S. of root showing sclerenchymatous net(x40)

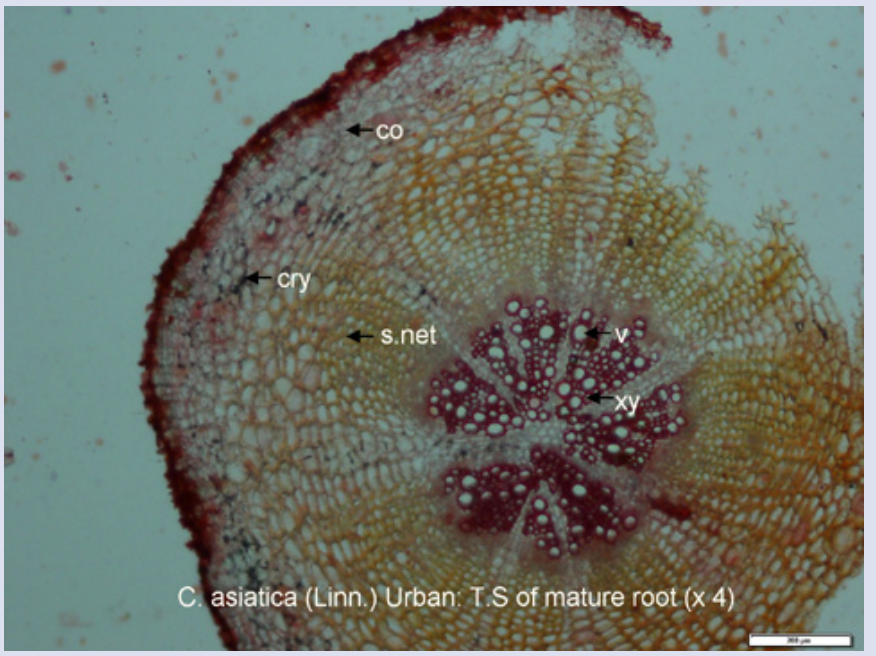

Figure 2d: Centella asiatica (Linn.)Urban: T.S. of mature root (x4)

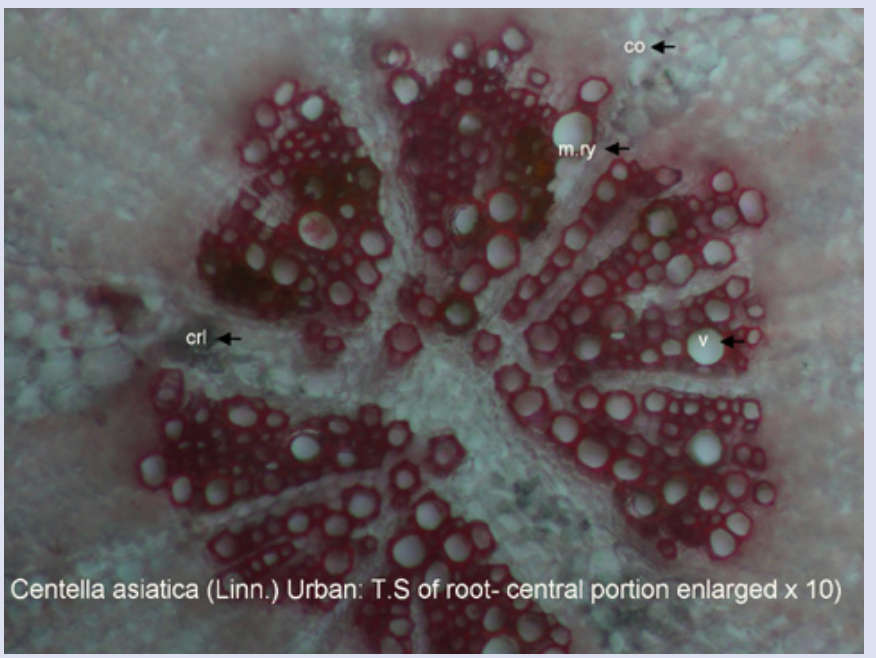

Figure 2e: C.asiatica (Linn.)Urban: T.S. of mature root- central portion enlarged (x 10) 


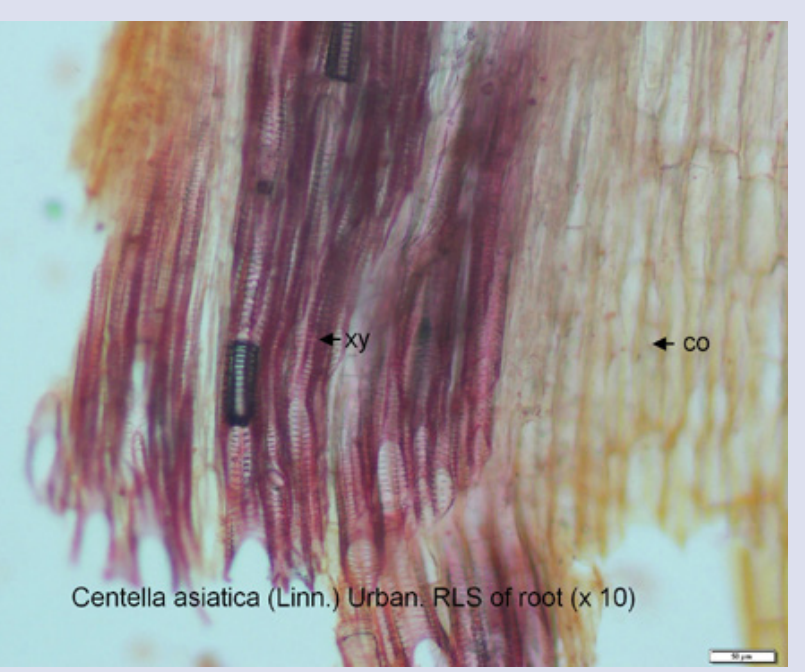

Figure 2f: Centella asiatica (Linn.) Urban:RLS of root $(\times 10)$

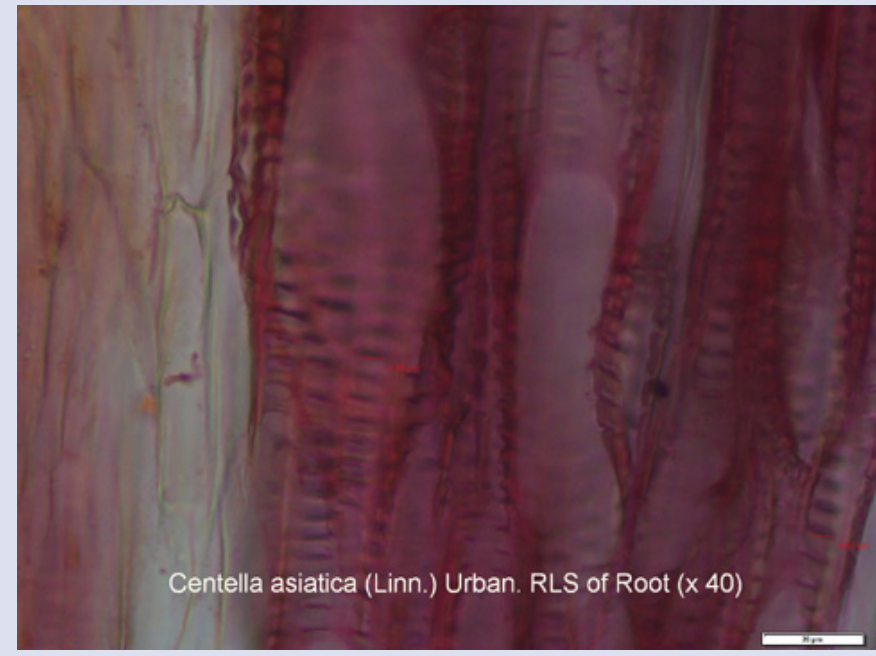

Figure 2g: Centella asiatica (Linn.) Urban: RLS of root $(\times 40)$

body ranged from $35.1 \times 40.3$ to $30.4 \times 97.8 \mu \mathrm{m})$, and were bordered by a layer of brachysclereids (Figure $3 \mathrm{~b}$ ). The secondary wall of brachysclereids (mean dimension of sclereid cell $23.3 \times 43.2 \mu \mathrm{m}$ ) were seems to have wide lumen and devoid of striations. Some of cortical cells contained simple starch grains. Starch grains were small in size (diameter ranged from 3.5 to $4.6 \mu \mathrm{m}$ ) and starch grains were round to elliptical in shape. Cross section of stem showed several (16-17) free vascular strands were arranged in form a ring. Each vascular strand was separated from one another by wide areas of parenchymatous tissues. Xylem element was represented mostly by a few vessels (Figure 3d); xylem fibers were either absent or poorly developed. Vessels were mostly solitary, ovoid to polygonal in shapes (Figure 3e). Diameter of vessel lumen ranged from 18.6 to $60.3 \mu \mathrm{m}$, with a mean diameter of $40.2 \mu \mathrm{m}$.Secondary wall thickening of the vessels was of spiral type (Figure $3 \mathrm{~g}$ ). In transverse longitudinal section (RLS), vessels were observed to have aligned in distorted fashion (Figure 3f) rather than linear or straight. This typical pattern for alignment of the xylem elements of stem could be considered as a feature characteristic of the taxon. Pith was broad, centrally placed and perenchymatous. Cells of the pith contained crystals of calcium oxalate and colored secretary substances (Figure 3).

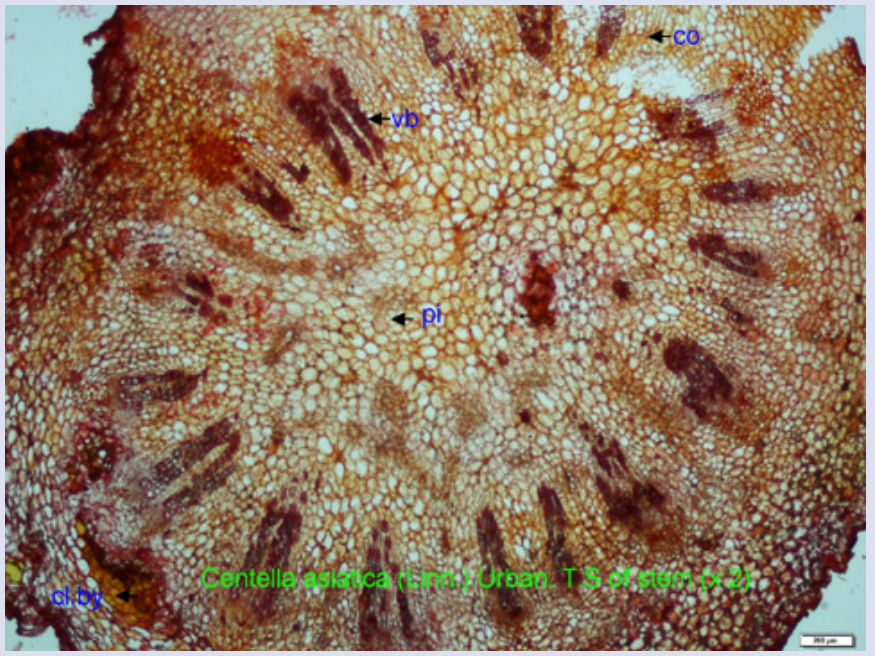

Figure 3: Centella asiatica (Linn.)Urban: T.Sof stem (x 2)

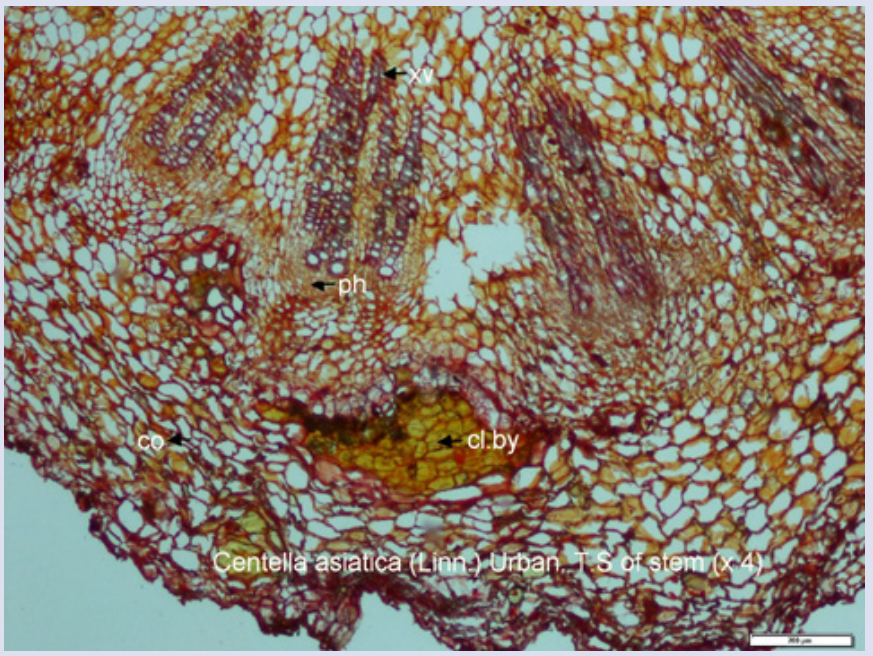

Figure 3a: Centella asiatica (Linn.)Urban: T.S of stem (x40)

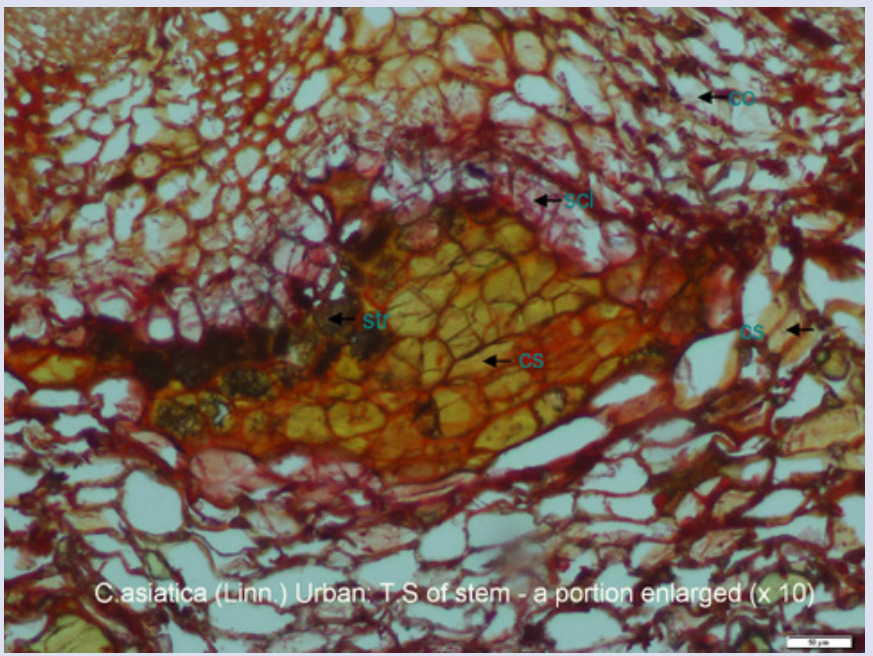

Figure 3b: Centella asiatica (Linn.)Urban: T.S of stem - a portion enlarged (x10) 


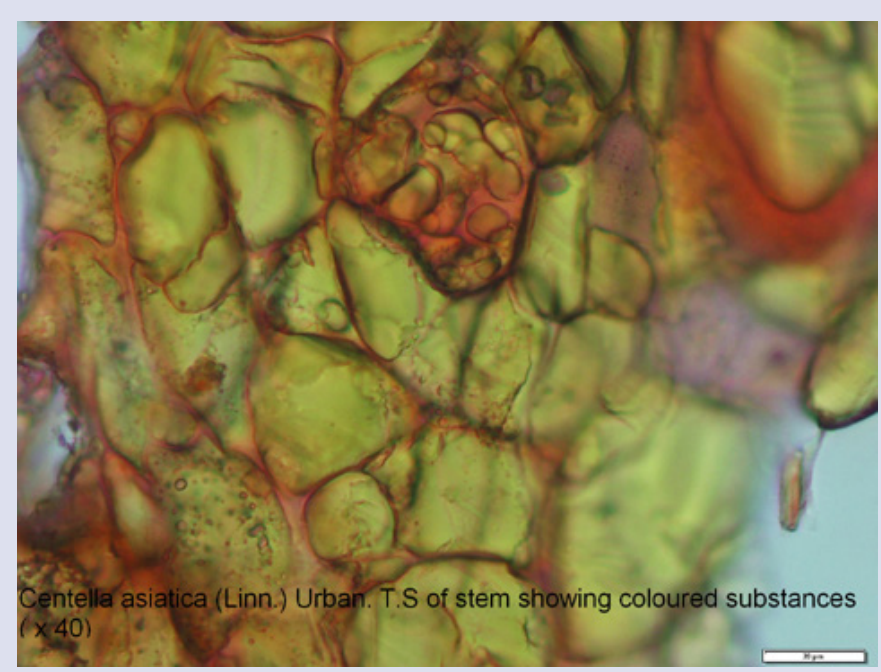

Figure 3c: C.asiatica (Linn.)Urban: T.S of stem - showing coloured substances $(x 40)$

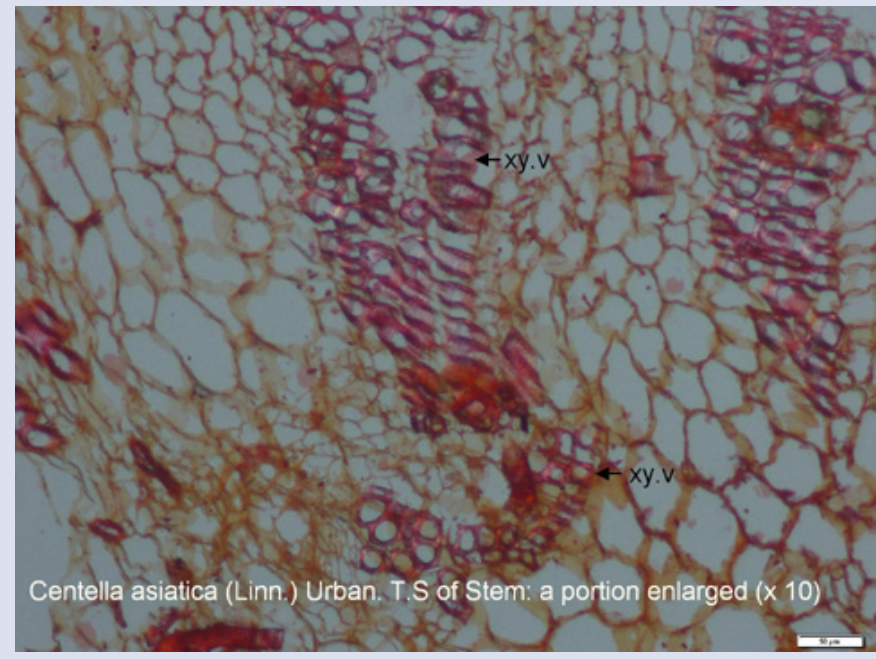

Figure 3d: Centella asiatica (Linn.)Urban:T.S of stem - a portion enlarged (x 10)

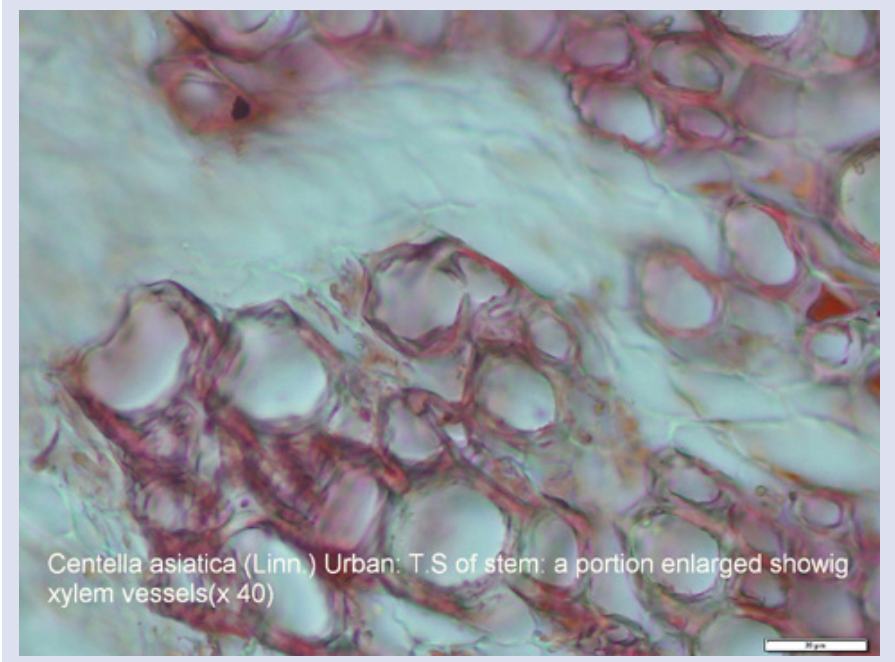

Figure 3e: C.asiatica (Linn.)Urban: T.S of stem - a portion enlargedxylem vessels $(x 40)$

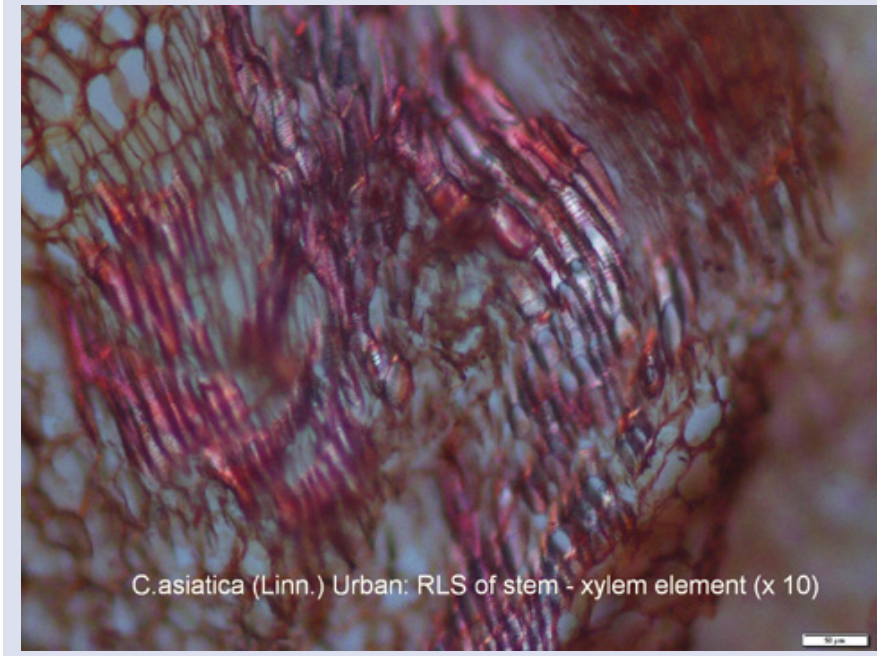

Figure 3f: Centella asiatica (Linn.)Urban. RLS of stem - xylem element (x 10)

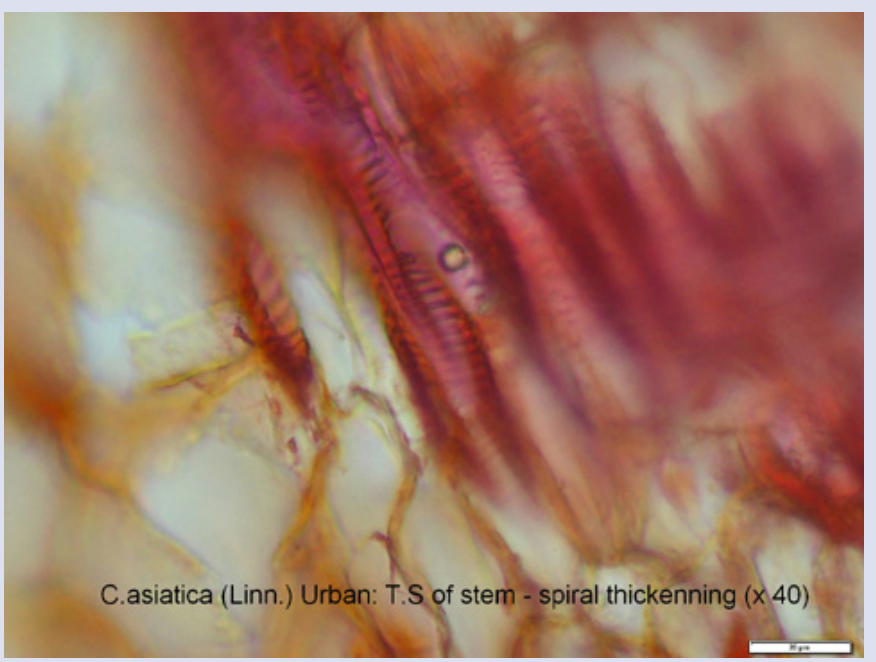

Figure 3g: C.asiatica (Linn.)Urban. RLS of stem - spiral thickening (x 40)

\section{Microscopic evaluation of stolon}

The stolon is slender, elongated and cylindrical about $2-3 \mathrm{~mm}$ in diameter, and brown in color. In cross sectional view, the stolon appeared irregularly circular in outline with tissue organization as outer epidermis, middle cortex and inner stele (Figure 4). The epidermis was uni-layered and covered by a conspicuous cuticle. Underneath the epidermis, the collenchyma consisted of three cell layers (Figure $4 \mathrm{~b}$ ). The cortex forms comparatively broad zone consisted of 8-10 layered parenchymatous tissues. Outer cortex consisted of 2-3 layers of small sized cells followed by relatively large sized parenchymatous cells, constituted to form the inner cortex. Parenchyma cells were polygonal in shape with slightly thickened walls; cortical cells were loosely arranged leaving small air spaces (arenchyma) in the cortical parenchyma (Figure 4b \& 4c). Like the cortical cells of the root, crystal idioblasts of calcium oxalate of various sizes and shapes were embedded in the cortical parenchyma, which provide mechanical support to stolon. The size of crystal idioblasts ranged from 14.9 × 31.5 to 18.5 × $37.9 \mu \mathrm{m}$. Vascular bundle was conjoint, collateral and open. The vascular tissues form a continuous cylinder 


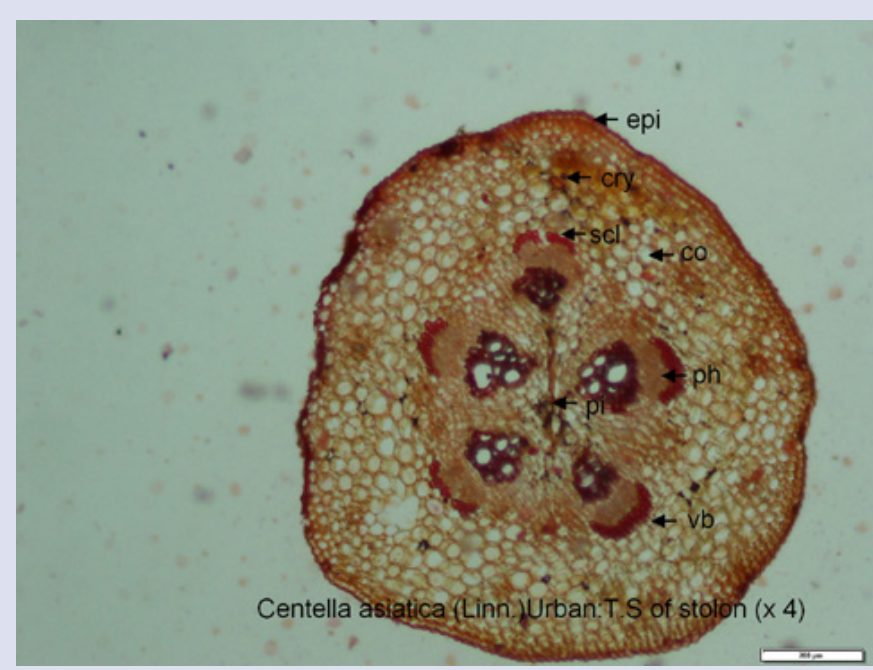

Figure 4: Centella asiatica (Linn.) Urban:T.S of stolon (x 4)

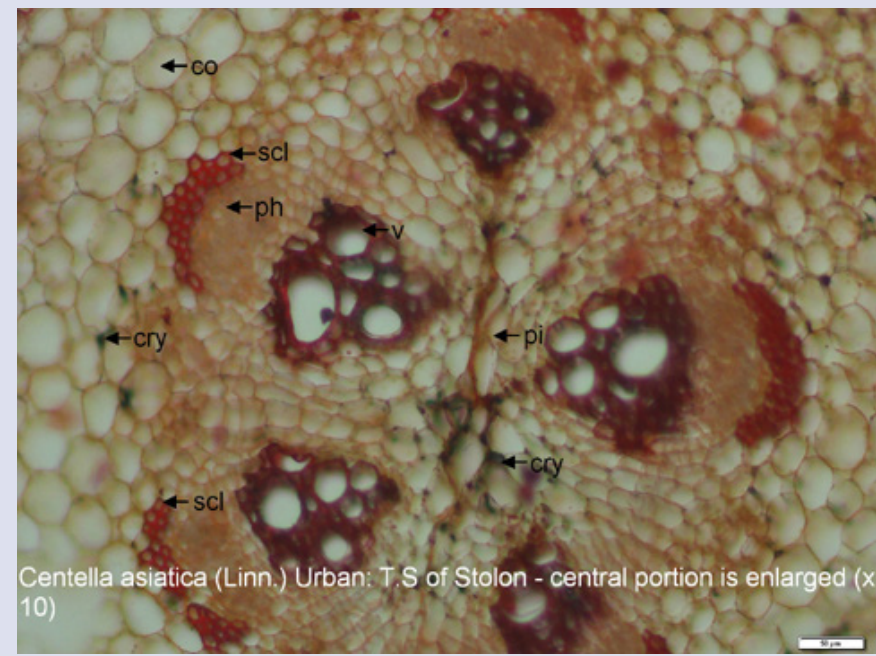

Figure 4a: C. asiatica (Linn.)Urban: T.S of stolon- central portion enlarged (x 10)

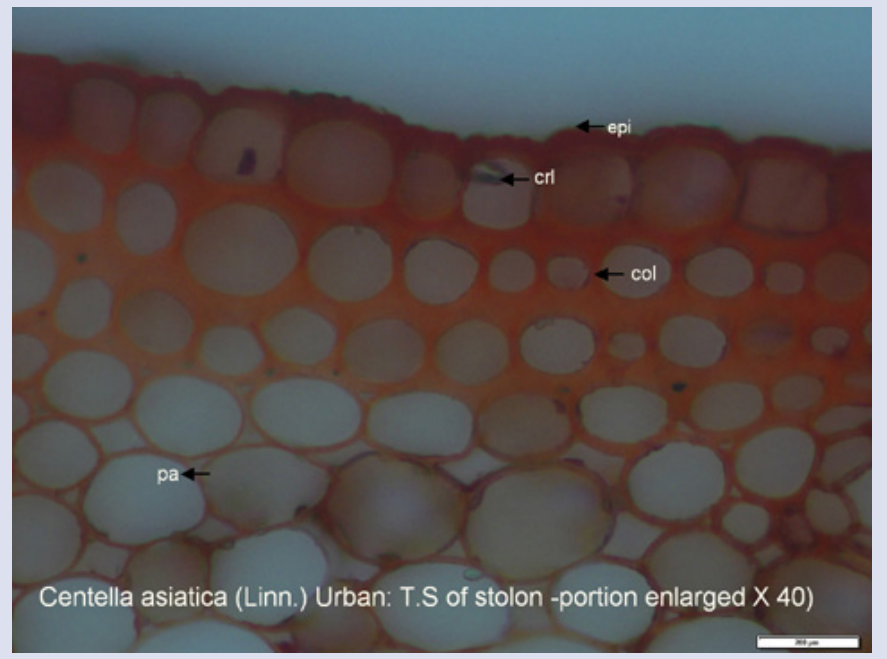

Figure 4b: Centella asiatica (Linn.) Urban: T.S of stolon- a portion enlarged (x 40)

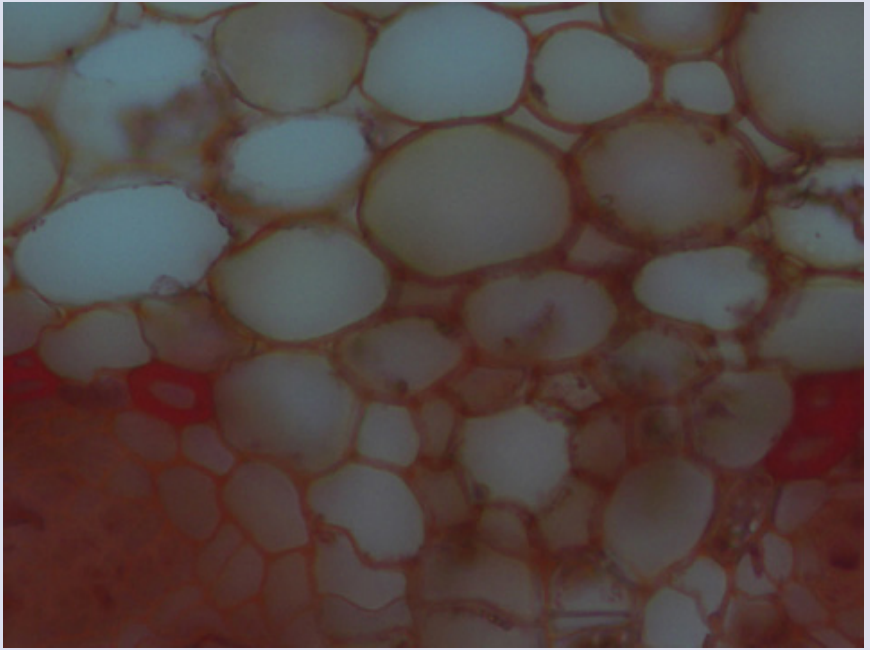

Figure 4c: Centella asiatica (Linn.) Urban: T.S of stolon- a portion enlarged (x 40)

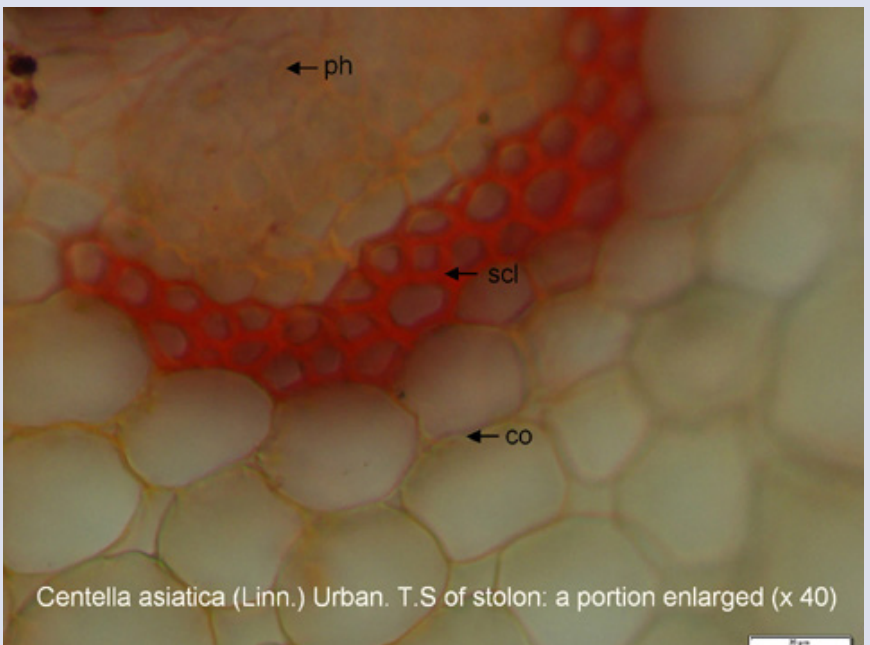

Figure 4d: Centella asiatica (Linn.) Urban: T.S of stolon- a portion enlarged (x 40)

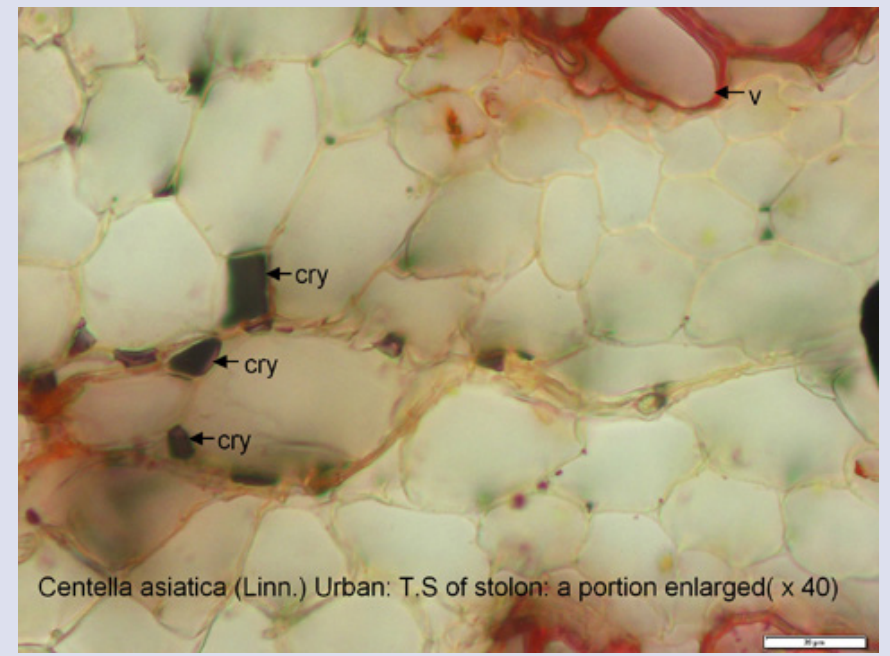

Figure 4e: Centella asiatica (Linn.) Urban: T.S of stolon- a portion enlarged (x 40) 
with periphloematic sclereids arches over the cylinder (Figure 4d). The vascular cylinder was five, arranged in the form a ring (Figure 4 \& 4a). Xylem elements appeared highly reduced and represented by vessels alone. Xylem vessels were arranged in radial rows of 4-5 and were polygonal in shape (Figure 4f). The mean diameter of lumen was found to be $20.5 \mu \mathrm{m}$. Phloem was aligned towards the adaxial side and xylem towards the abaxial side. Inter-vascular parenchyma often contained secretary canals; wall of the canal was encircled by 6-7 rectangular cells, which seemed to be arranged in the form of a wreath (Figure 4c). Some parenchyma cells were found to be filled with starch grains. Stolon contained centrally located pith. Pith cells were circular or polygonal shape. Cells located near the centre had thinner walls and contained the crystal idioblasts (Figure 4e).

\section{Microscopic evaluation of leaves}

Centella asiatica (Linn.) Urban, leaves had an average length of about $3.5 \mathrm{~cm}$ and width of $1.5 \mathrm{~cm}$ (Figure 1b). Leaves have no characteristic taste and odour. Lamina was dorsiventrally differentiated and made of epidemics, mesophyll and vascular tissues (Figure 5). Both epidermises were uniseriate, composed of compactly arranged rectangular cells with moderately striated outer walls. Cuticle appeared either completely absent or poorly developed (Figure 5 \& 5a). Non-cuticular striated epidermis which may facilitate the steady absorption of water from the surrounding. Some of the upper and lower epidermal cells located at the midrib portion were provided with uniseriate, trichomes. The presence of trichome in leaves may be considered as a land habitat; in general trichomes can play a role in the regulation of plant temperature, light reflection, defense against herbivores, and reduction of water loss. ${ }^{32}$

Beneath the abaxial epidermis contained a patch or band of sclerenchymatous tissues (Figure 5a) made of 4-5 layers, which may provide tensile strength to adaxial side of the mid vein. Lamina was flat and much reduced in dimension compared to the midrib. The mid rib seemed to have a slight depression on the adaxial side with broadly semicircular on the abaxial side (Figure 5). Midrib was composed of epidemics, collenchyma, mesophyll and vascular bundle. Lamina was dorsi-ventrally differentiated, with adaxial mesophyll having a compact palisade parenchyma with one layer of elongated, and barrel shaped cells. Mesophyll contained crystal idioblasts, both towards the adaxial and abaxial tissues of the midrib (Figure $5 b \& 5 c$ ). Cells of the mesophyll were found filled with plenty of chloroplasts (Figure 5b). The size of the individual palisade ranged from 158 to $663 \mu \mathrm{m}$ in length with a mean length of about $367 \mu \mathrm{m}$. The spongy parenchyma composed of 3-4 layers of oval to rectangular cells, loosely arranged with wide intercellular spaces. They form about $3 / 4$ of total area of the midvein. A parenchymatous bundle sheath was encircled the vascular strand. Lamina also possessed vasular traces, but not differentiated into distinct metaxylem and protoxylem. The palisade ratio was found to be about 2 .

\section{Microscopic evaluation of Petiole}

The petiole had dorsiventral differentiation, with a prominent groove or furrow on its ventral side (Figure 1b). Dorsal side of the petiole comprised of five sides (pentagonal shape), with a deeply notched groove on the ventral side (Figure 6). A chlorenchyma zone consisting of 4-6 layers of cells was located beneath the epidermis, followed by a broad parenchymatous zone. The 5 free vascular bundles were aligned in the middle of the ground tissue; bundles appeared directed towards the five corners of the pentagon (Figure 6a). The vascular tissues form a continuous cylinder, with a band of periphloematic sclereids (Figure 6b) arches over each vascular cylinder. Vascular strands were separated from one another by wide areas of ground tissues. Xylem vessels were aligned in radial rows of two, with phloem on the adaxial side (Figure 6b).

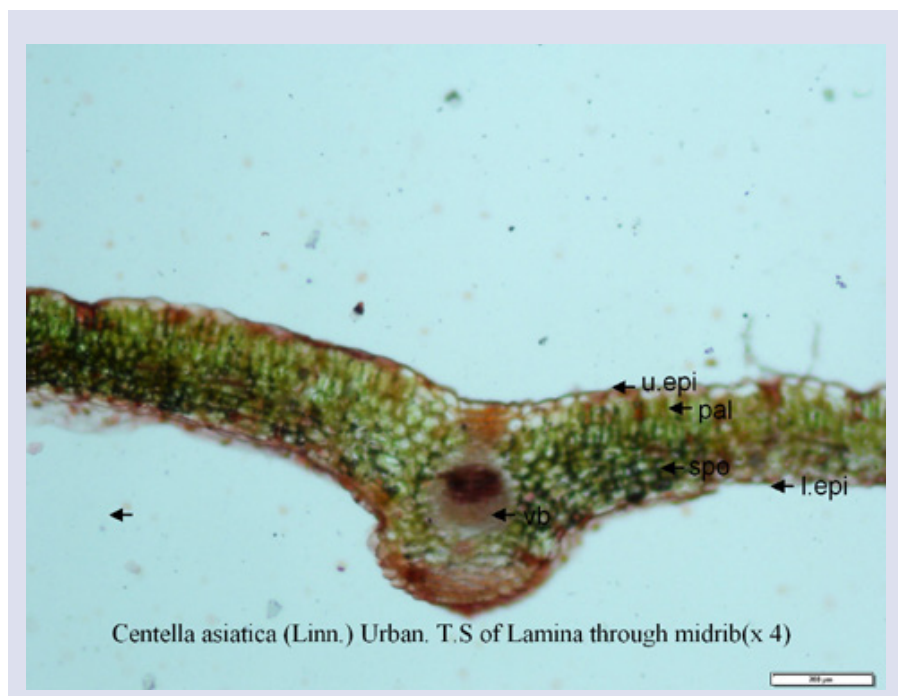

Figure 5: Centella asiatica (Linn.) Urban:T.S. of lamina through midrib(x 4)

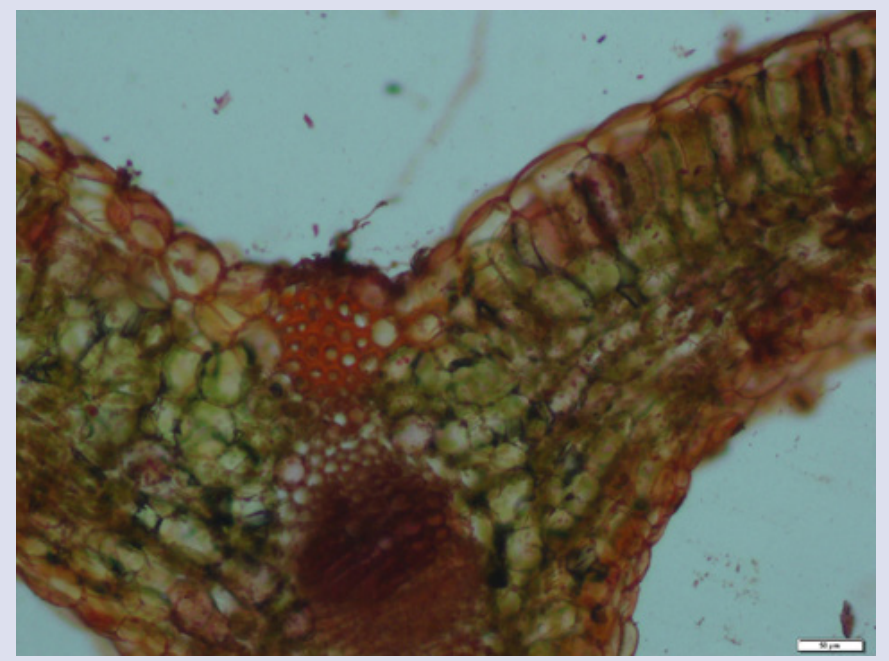

Figure 5a: Centella asiatica (Linn.) Urban: T.S. of lamina through midrib(x 10)

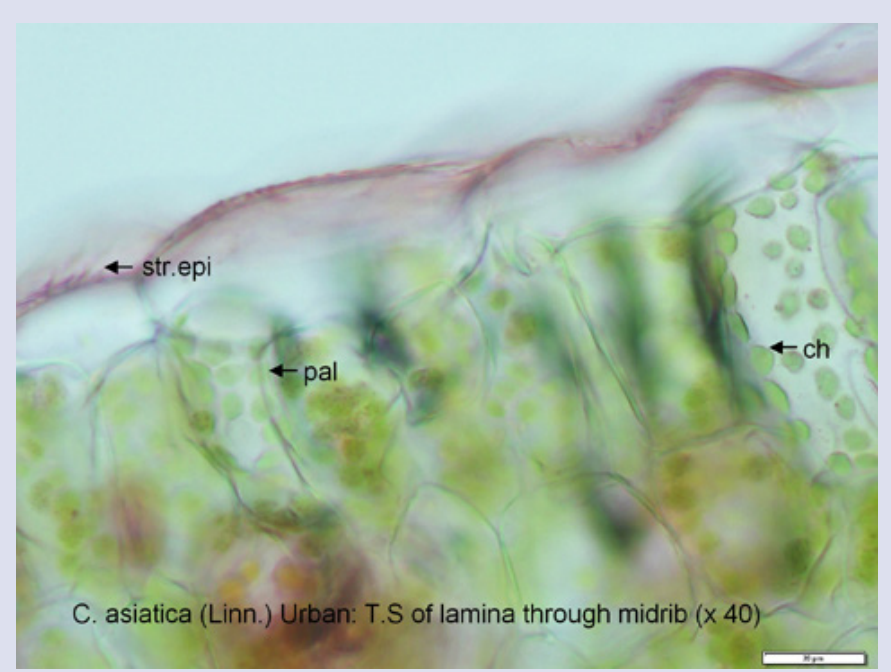

Figure 5b: Centella asiatica (Linn.) Urban:a portion of midrib is enlarged(x 40) 


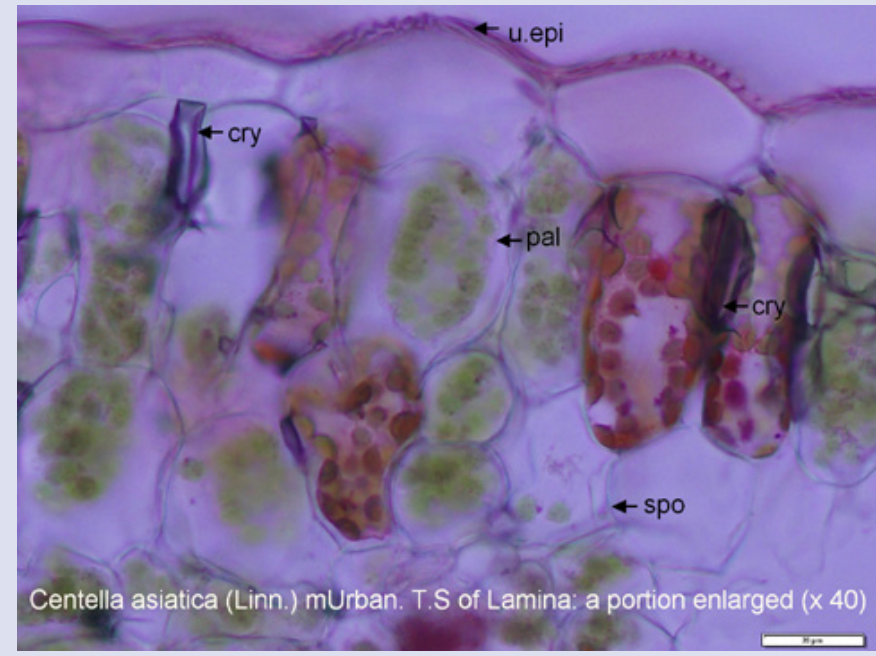

Figure 5c: Centella asiatica (Linn.) Urban:T.S. of Lamina- a portion enlarged(x 40)

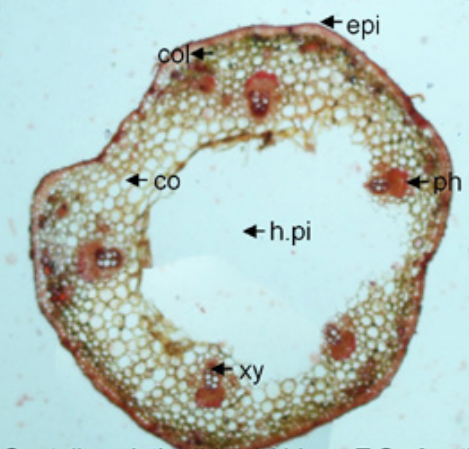

Centella asiatica(tinn.) Urban. T.S of petiole $(\times 2)$

Figure 6: Centella asiatica (Linn.) Urban: T.S. of petiole $(\times 2)$

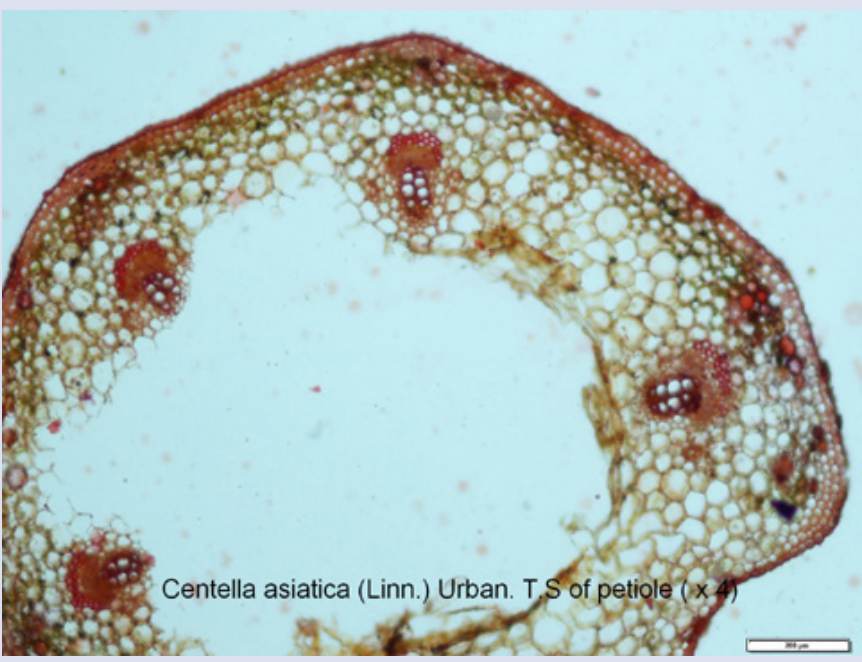

Figure 6a: Centella asiatica (Linn.) Urban: T.S. of petiole $(\times 4)$

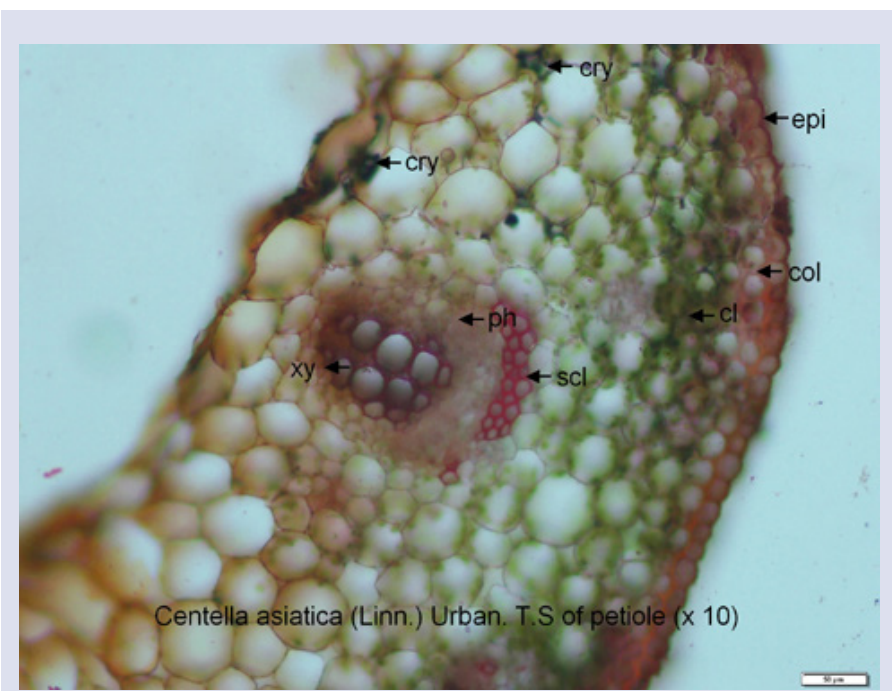

Figure 6b: Centella asiatica (Linn.) Urban: a portion of petiole enlarged $(\times 10)$.

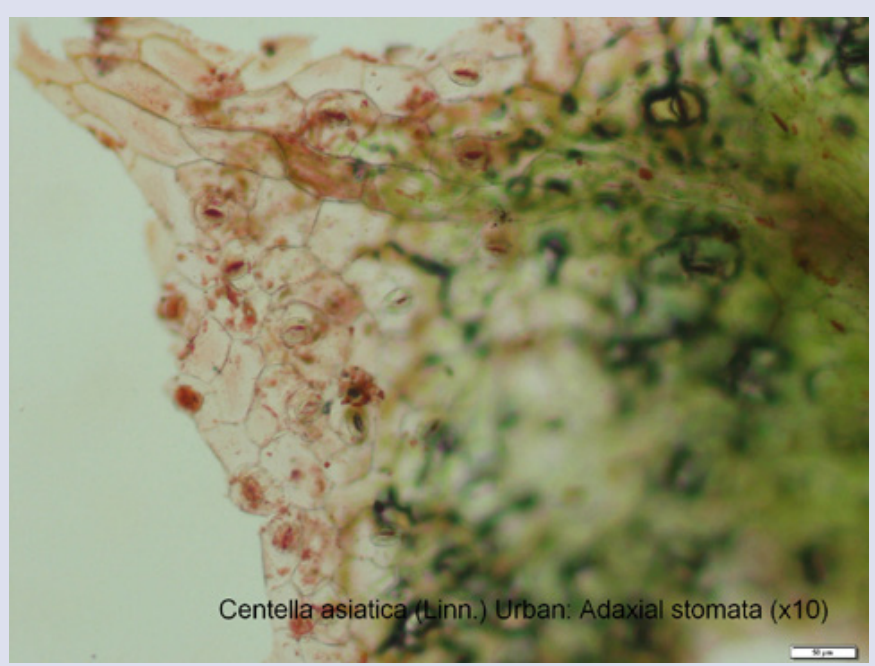

Figure 7: Centella asiatica (Linn.) Urban: Adaxial stomata $(\times 10)$

The vascular cylinder appeared encircled by a parenchymatous bundle sheath, enclosing both the xylem and phloem. Crystal idioblasts (Figure 6b) were found embedded between the intervening walls of cortical parenchyma. The cross section of petiole had a prominent central hollow core of air canal or lacuna. The morphogenesis of arenchyma lacunae, according to Seago et $a l^{33}$ may occurred either by the process of the programmed cell death (Lysogeny) or schizogenic separations of the adhering cell of the original ground tissues.

\section{Epidermal characters}

Leaves of this species are amphistomatic and stomata were found to be animocytic (Figure 7, 7a \& 7b) type. Anticlinal walls of both adaxial and abaxial epidermal cells were straight (Figure 7\& 7a). There were more stomata on the abaxial surface than on the adaxial surface, and stomatal distribution was random. The mean length and breadth of lower stoma was observed as $25.3 \times 21.8 \mu \mathrm{m}$ and that of the upper stoma was found to be of $18.7 \mu \mathrm{m} \times 17.6 \mu \mathrm{m}$. Guard cell area (GCA) of lower surface was found to be $482.1 \mu \mathrm{m}^{2}$ and that of upper surface $287.6 \mu \mathrm{m}^{2}$. The number 
of abaxial epidermal cells and abaxial stomata per square millimeter area of the leaf were observed as 1125.2 and 270.5 respectively and stomatal index for the lower surface was found to be 19.3

\section{Venation pattern}

Venation patterns of cleared petiolated leaves with crenate margins had shown the major leaf venation pattern of actinodromous (Figure 8 ) under low $(\times 2)$ magnification. Areolation was well developed and appeared pentagonal in shape (Figure $8 \mathrm{a}$ ) with area of areoles ranged from 0.027 to $0.033 \mathrm{~mm}^{2}$. The free ending ultimate veins of the leaves branched twice (Figure 8a) and marginal ultimate venation was fimbrial. The cleared leaves under polarized microscopy contained plenty of crystals of calcium oxalate in lamina and appeared strongly birefringent (Figure 8a \& 9a).

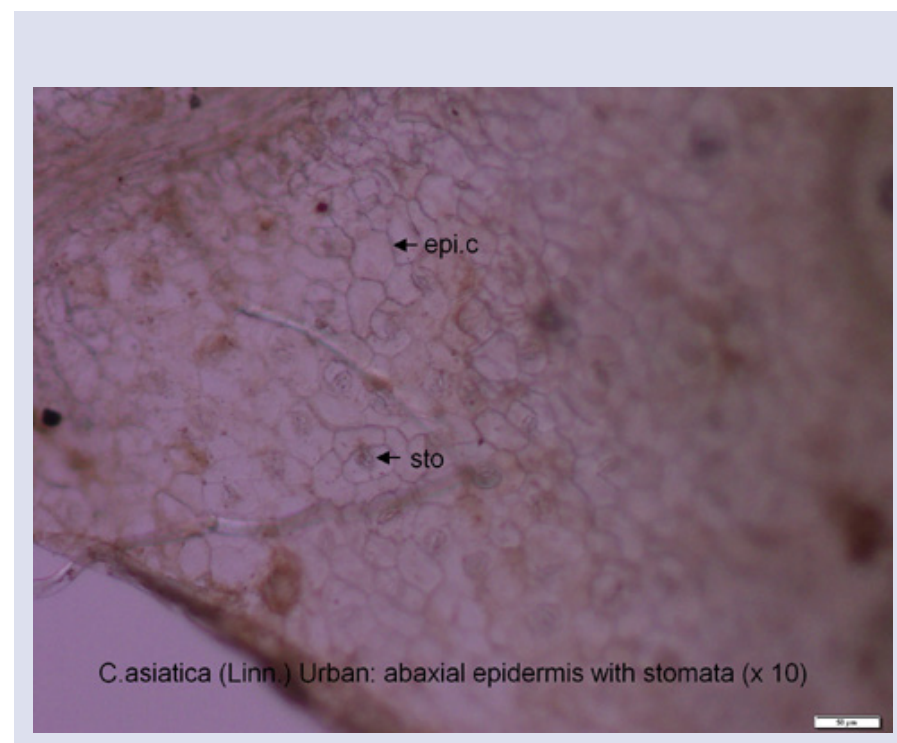

Figure 7a: Centella asiatica (Linn.) Urban: Abaxial epidermis with stomata $(\times 10)$

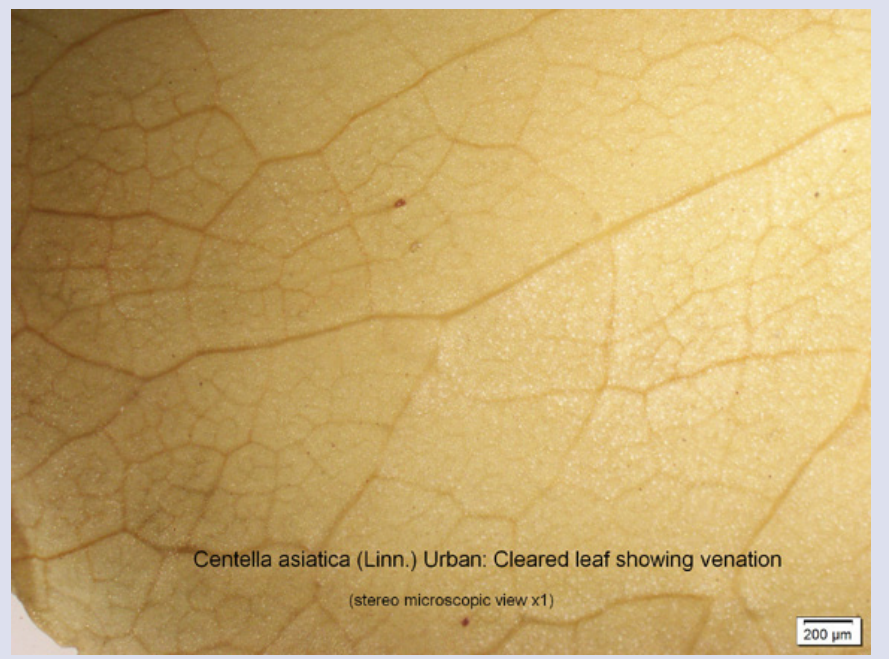

Figure 8: Centella asiatica (Linn.)Urban: Cleared leaf -venation (stereo microscopy $\times 1$ )

\section{Powder microscopy}

The dried leaves and root of Centella asiatica were analyzed for powder characteristics. Microscopic examination showed fragments of leaf epidermis with venations (Figure 9), prismatic crystals of calcium oxalate in idioblasts (Figure 9a \& 9b) and crystals appeared strongly birefringent under polarised microscopy (Figure 9c). Root powder showed fragments of sclerenchyma netting (Figure 9e, 9f \& $9 \mathrm{~g}$ ) and fragments of parenchyma cortex with clusters of simple starch grains(Figure 9d).

\section{CONCLUSION}

The present study reports the occurrence of crystals in the idioblasts as calcium oxalate of diverse forms and sizes in the parenchyma of different organs such as the stem, root, stolon, petiole, lamina and mesophyll. Such

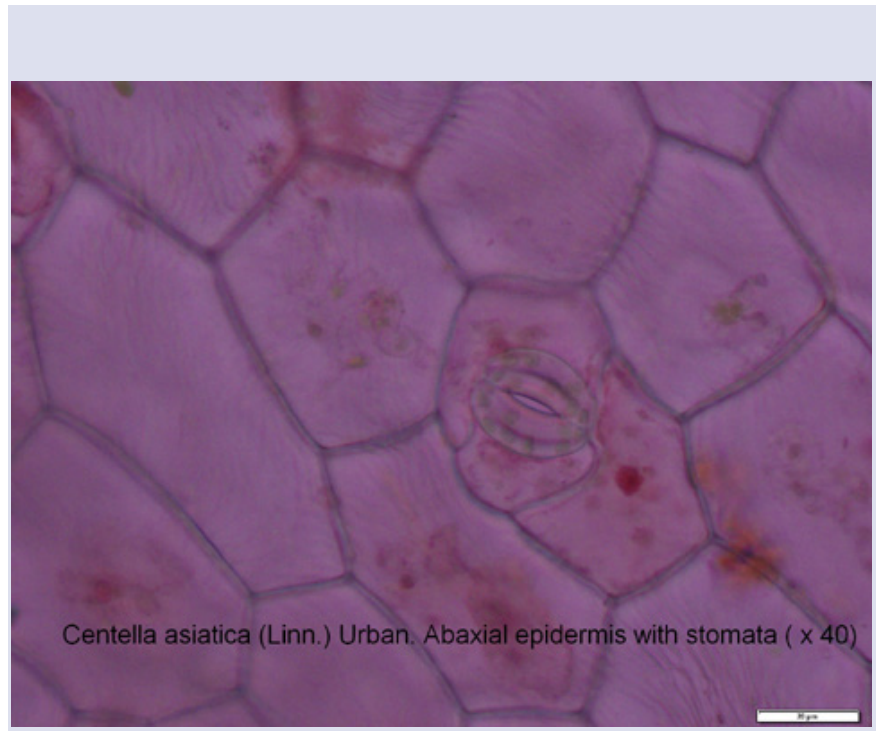

Figure 7b: Centella asiatica (Linn.) Urban: Abaxial epidermis with stomata $(\times 40)$

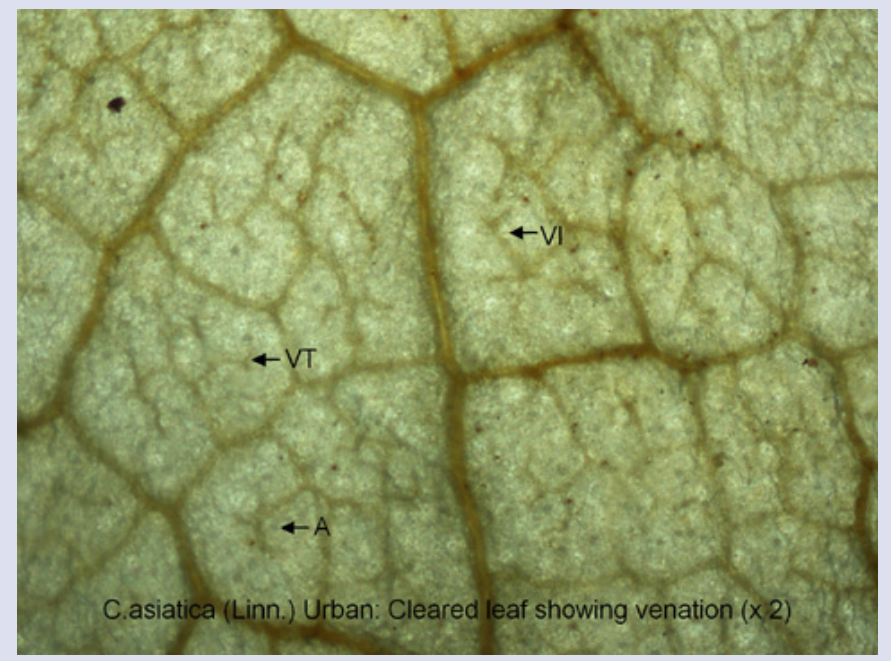

Figure 8a: Centella asiatica (Linn.) Urban: Cleared leaf showing venation( $(x 2)$ 


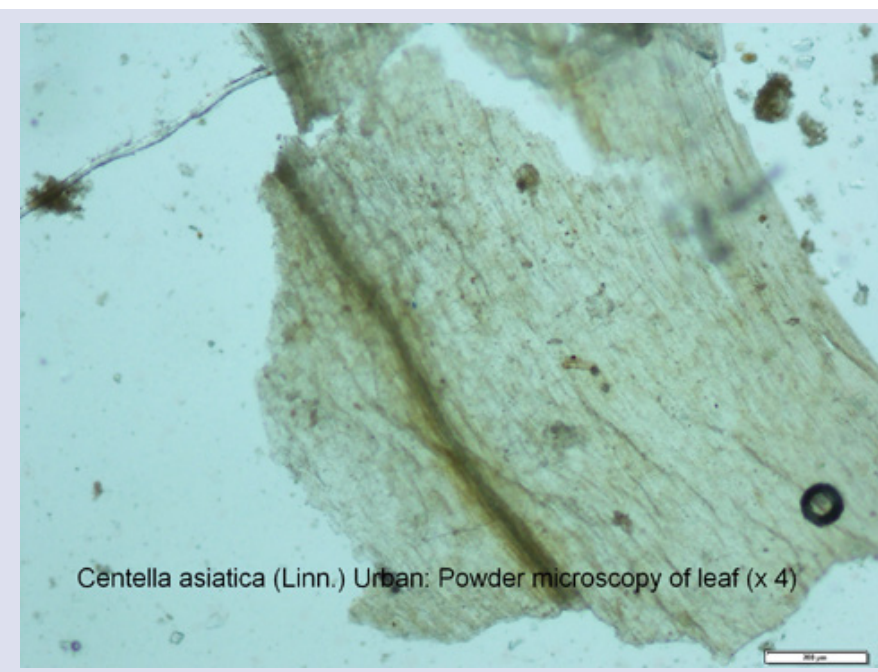

Figure 9: Centella asiatica (Linn.)Urban: Powder microscopy of leaf (x 4)

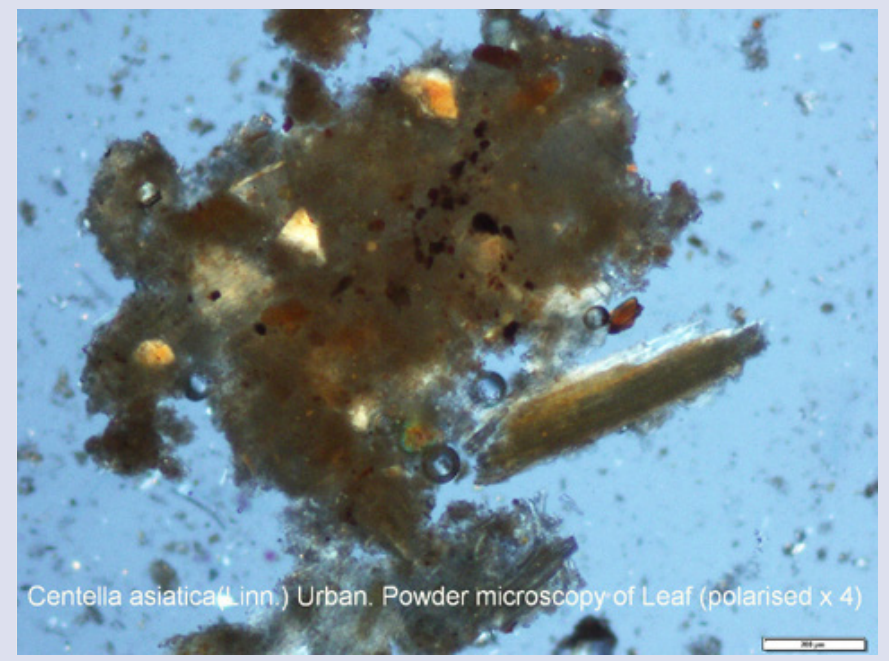

Figure 9b: Centella asiatica (Linn.) Urban: Powder - leaf (polarised microscopy $\mathrm{x}$ 4)

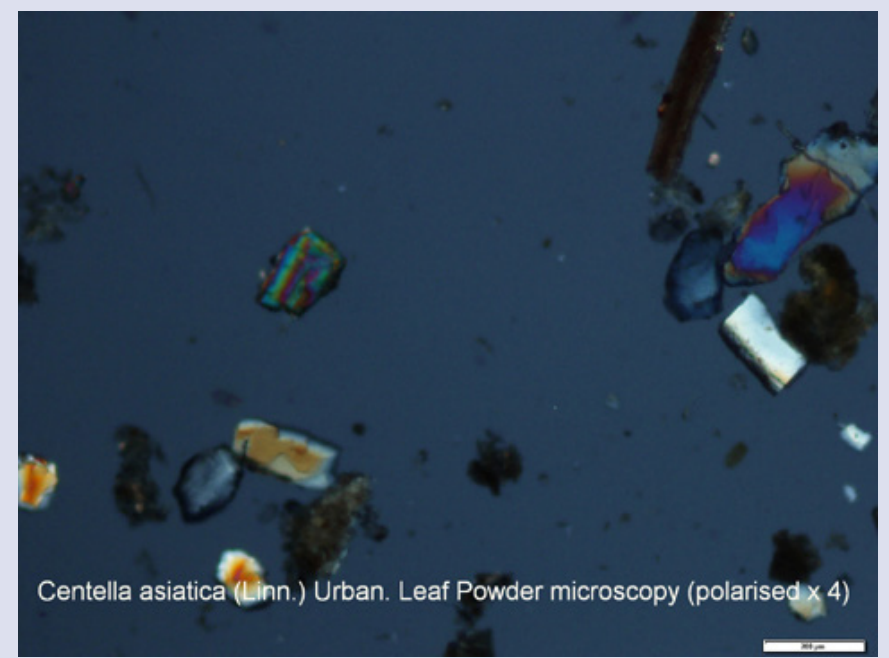

Figure 9c: Centella asiatica (Linn.)Urban: Powder- leaf (polarised microscopy $\times 4$ )

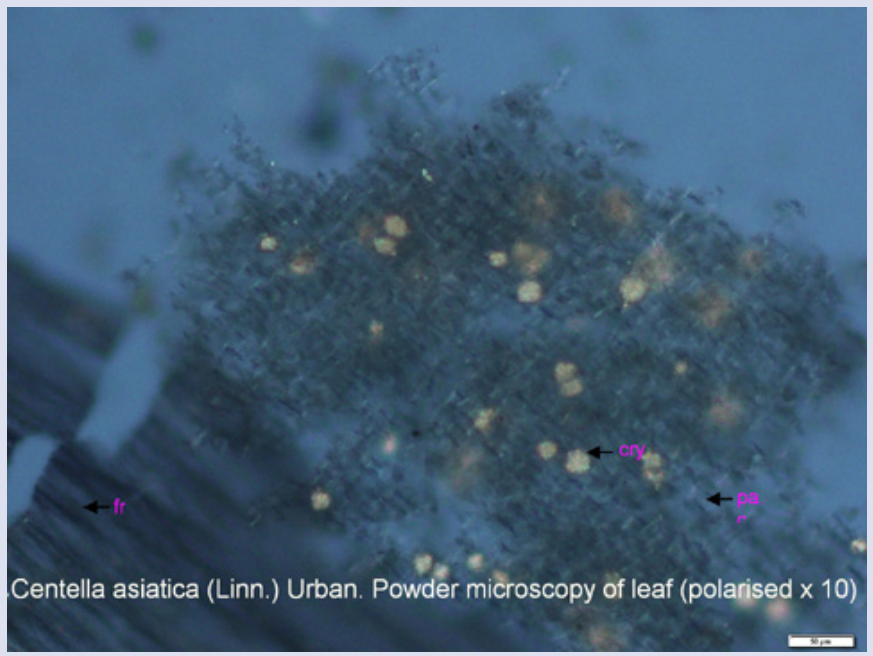

Figure 9a: Centella asiatica (Linn.) Urban:Powder -leaf (polarized microscopy $x 10$ )

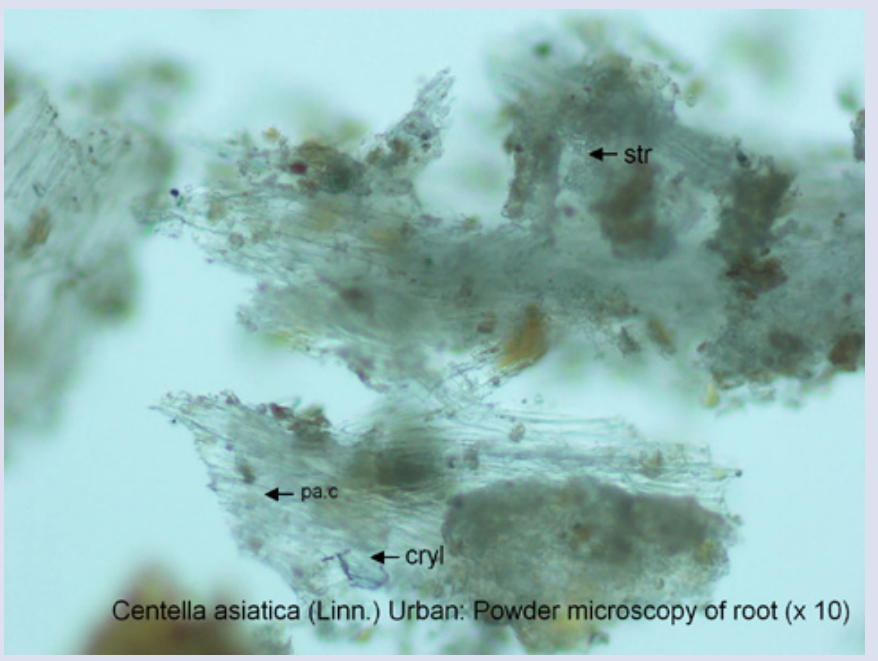

Figure 9e: Centella asiatica (Linn.) Urban: Powder microscopy of root (x 10)

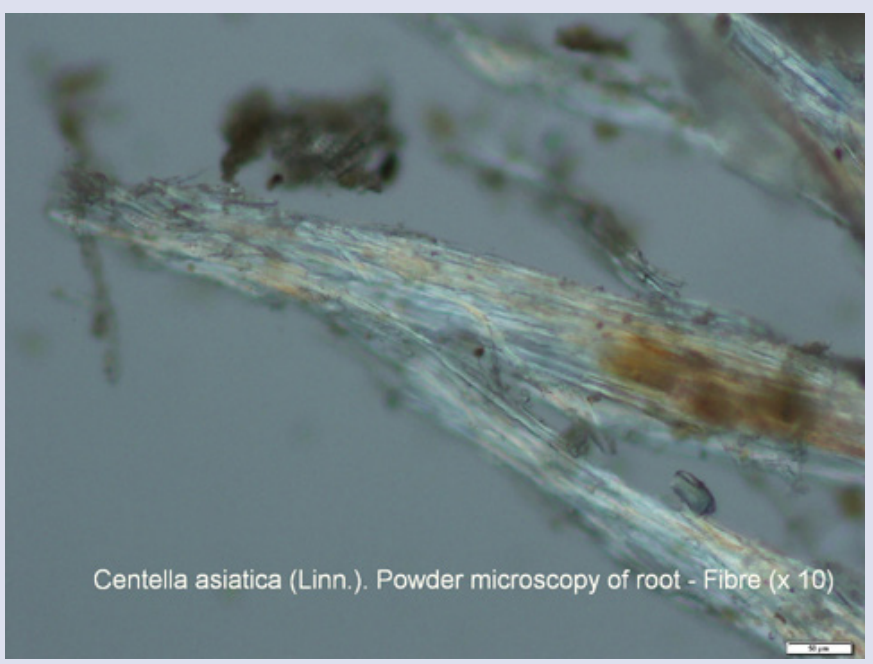

Figure 9f: Centella asiatica (Linn.) Urban: Powder microscopy of root (x 10) 


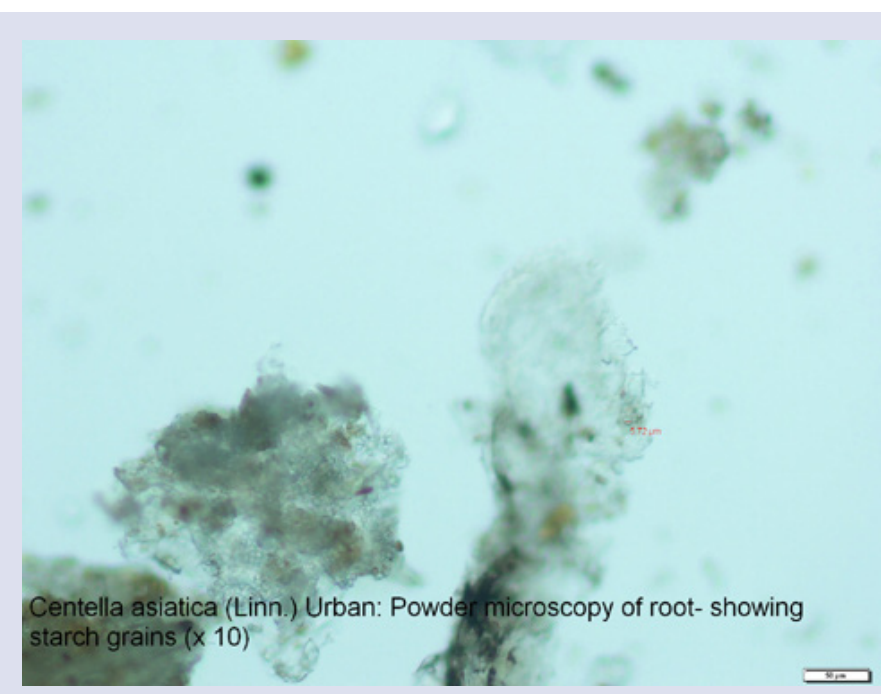

Figure 9d: Centella asiatica (Linn.) Urban: Powder microscopy of rootstarch grains $(x 10)$

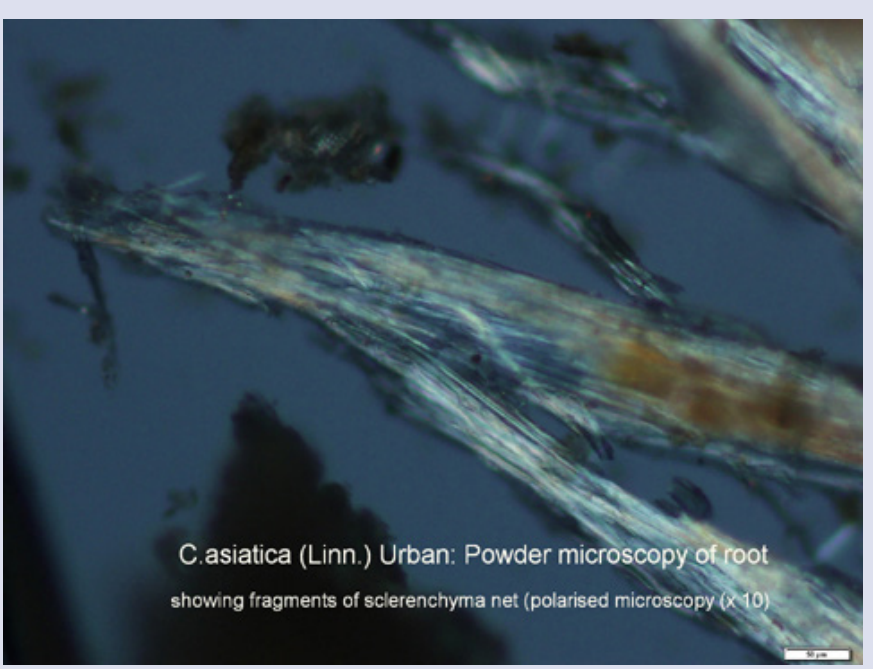

Figure 9g: C.asiatica (Linn.) Urban: Powder - root- sclerenchyma net (polarised $\times$ 40) crystal idioblasts may provide mechanical strength to delicate parenchyma cells thereby enhancing the tissue strength of helophytes or marsh plants, in addition to the general roles of the crystals, in the regulation of calcium influx of cell, reflectance of light, protection against herbivores, and detoxification of heavy metals. ${ }^{34}$ Presence of cortical arenchyma of root and stolon, central air canal of the petiole had adaptive value for wetland habitat, allowing plants to succeed in hypoxic or anoxic condition of the flooded or waterlogged areas. Similarly, the anatomical features such as the reduction in lignified elements, xylem element represented mostly by vessels alone, non-cuticular striated epidermis of lamina observed in C. asiatica could explain why the species - although not strictly from dry habitats is found growing near bodies of water.

These findings in conjunction with sclerenchymatous net in root cortex, periphloematic sclereids in petioles and stolon could be remarkable anatomical markers useful for identifying the taxon, especially in the context of the reports on the availability such standards or pharmacognostical markers for authentication of crude drug materials had severely been limited for Centella asiatica (Linn.) Urban.

\section{ACKNOWLEGEMENT}

None.

\section{CONFLICT OF INTEREST}

Author has declared that no conflict of interest exists.

\section{ABBREVAITIONS USED}

A:Areole; ABX.E: Abaxial epidermis; ADAX.E: Adaxial epidermis; ARCH: arenchyma; $\mathrm{CH}$ : Chlorophyll; CHM: Chlorenchyma; CL.BY: Colored body; CO: Cortex; COL: Collenchym; CRL, CRY: Crystal; CUT: Cuticle; EPI.C: Epidermal cell ;EPI: Epidermis; GU.C: Guard cell; L.UP: Lower epidermis; PAL: Palisade cell; PHO: Phloem; PI: Pith; SCL: Sclerenchymatous periphloemic fiber; SPO: Spongy parenchyma; SS: Secretary substance; ST: Stomata; STO: Stone cell; STR: Starch grain; STR.EP: Striated epidermis; S.XY: Secondary xylem; TRI: Trichome; XY: Xylem; U.EPI: Upper epidermis; VB: Vascular bundle; VI: Vein islet; VT: Veinlet termination.

\section{REFERENCES}

1. Lariushin B. Apiaceae Family. Vol.2. Published by B.Lariushin; 2012.p.346. ISBN:1480168793.

2. Chopra RN, Nayar SL, Chopra IC. Glossary of Indian Medicinal Plants (Including the Supplement) New Delhi: Council of Scientific and Industrial Research; 1986.p.51-83.

3. Hashim P, Sidek H, Helan MH, Sabery A, Palanisamy UD, Ilham M. Triterpene composition and bioactivities of Centella asiatica. Molecules. 2011;16(2):1310-22 doi:10.3390/molecules16021310

4. Kashmira GJ, Jagruti PA, Anuradha GK. Pharmacological Review on Centella asiatica: A potential herbal cure-all. Indian J Pharm Sci. 2010;72(5):546-556. doi: 10.4103/0250-474X.78519.

5. James JT, Dubery IA. Pentacyclictriterpenoids from the medicinal herb, Centella asiatica (L.) Urban. Molecules. 2009;14(10):3922-41. doi:10.3390/ molecules14103922.

6. Bylka W1, Znajdek-Awizen P, Studzinska-Sroka E, Danczak-Pazdrowska A Brzezinska M. Centella asiatica in dermatology: An overview. Phytother Res. 2014;28:1117-24. doi: 10.1002/ptr.5110.

7. Bradwejn J, ZhouY, Koszycki D, Shlik J. A double-blind, placebo-controlled study on the effects of gotu kola (Centella asiatica) on acoustic startle response in healthy subjects. J Clin Psycho Pharmacol. 2000;20(6):680-84. https://www. ncbi.nlm.nih.gov/ pubmed/11106141.

8. Oyedeji OA, Afolayan AJ. Chemical composition and antibacterial activity of the essential oil of Centella asiatica growing in South Africa. J Pharma Biol. 2005;43:249-52. http://dx.doi.org/10.1080/13880200590928843.

9. Lee MK, Kim SR, Sung SH, Lim D, Kim H, Choi H, Park. et al. Asiatic acid derivatives protect cultured cortical neurons from glutamate-induced excitotoxicity. Res Commun Mol Path Pharmacol. 2000;108(1-2):75-86. https://www. ncbi. nlm.nih.gov/ pubmed/ 11758977

10. Somboonwong J, Kankaisre M, Tantisira B, Tantisira MH. Wound healing activities of different extracts of Centella asiatica in incision and burn wound models: An experimental animal study. BMC Complement Altern Med. 2012;12(1):1-7. doi: 10.1186/1472-6882-12-103.

11. Maquart FX, Bellon G, Gillery P, Wegrowski Y, Borel JP. Stimulation of collagen synthesis in fibroblast cultures by a triterpene extracted from Centella asiatica. Connect Tissue Res. 1990;24(2):107-20. https://www.ncbi.nlm.nih.gov/pubmed/ 2354631.

12. Kumar MHV, Gupta YK. Effect of Centella asiatica on cognition and oxidative stress in inteecerebro ventricular streptozotocin model of Alzheimers' disease in rat. Clin Exp Pharmacol Physiol. 2003;30(5-6):336-42. https://www.ncbi.nlm. nih.gov/pubmed/ 12859423.

13. Khotimah $\mathrm{H}$, Ali M, Sumitro SB, Widodo MA. Decreasing $\alpha$-synuclein aggregation by methanolic extract of Centella asiatica in zebrafish Parkinson's model. Asian Pac J Trop Biomed. 2015;5(11):948-54. doi:10.1016/j.apjtb.2015.07.024.

14. Gnanapragasam A, Ebenezar KK, Sathish V, Govindaraju P, Devaki T. Protective effect of Centella asiatica on antioxidant tissue defense system against adriamycin induced cardiomyopathy in rats. Life Sci. 2004;76(5):585-97. doi: 10.1016/j. Ifs. 2004.09.009 
15. Bobade V, Bodhankar SL, Aswar U, Vishwaraman M, Thakurdesai P. Prophylactic effects of asiaticoside-based standardized extract of Centella asiatica (L.) Urban leaves on experimental migraine: Involvement of $5 \mathrm{HT} 1 \mathrm{~A} / 1 \mathrm{~B}$ receptors. Chin $\mathrm{J}$ Nat Med. 2015;13(4):274-82. doi: 10.1016/S1875-5364(15)30014-5.

16. Chen S, Yin ZJ, Jiang C, Ma Z-Q, FuQ, Qu R, et al. Asiaticoside attenuate memory impairment induced by transient cerebral ischemia-reperfusion in mice through anti-inflammatory mechanism. Pharmacol Biochem Behav. 2014;122:7-15. doi: 10.1016/ j.pbb. 2014.03.004

17. Diwan PV, Karwande I. Anti-anxiety profile of Mandukaparni(Centella asiatica) in animals. Fitoterapia. 1991;62:253-7.

18. Rao MGK, Rao MS, Rao GS. Centella asiatica (L.) leaf extract treatment during the growth spurt period enhances hippocampal CA3 neuronal dendritic arborization in rats. Evid Based Complement Alternat Med. 2006;3(3):349-57. doi: 10.1093/ecam/ nel024

19. Paocharoen V. The efficacy and side effects of oral Centella asiatica extract for wound healing promotion in diabetic wound patients. J Med Assoc Thai. 2010;93(Suppl 7):S166-70. https://www.ncbi.nlm.nih.gov/pubmed/21298840.

20. Deshpande PO, Mohan V, Thakurdesai P. Preclinical Safety Assessment of Standardized Extract of Centella asiatica (L.) Urban Leaves. Toxicol Int. 2015;22(1):10-20. doi: 10.4103/0971-6580.172251

21. Sharma J, Sharma R. Radioprotection of Swiss albino mouse by Centella asiatica extract. Phytother Res. 2002;16(8):785-86. doi: 10.1002/ptr.1069

22. Aiyer, NK, Kolmmal M. Centella asiatica Linn. In Pharmacognosy of Ayurvedic Drugs (Kerala). Vol. 1 series 8, Trivendrum: Department of Pharmacognosy, University of Kerala. 1964.p.29-30.

23. Joseph GVR, Chaturvedi, Deokule SS. Standardisation and Quality Evaluation of Centella asiatica Linn. Ancient Science of Life. 2001;20(4):99-110. PMCID: PMC3336405

24. Joshi VC, Khan IA. Morphological characterization of medicinal plant Centella asiatica (L.) Urb and detection of its possible substitutes. Planta Med. 2008;74:2. doi: 10.1055/s2008-1075198

25. Monnieri LRB, Asiatica C. In Upton R, Graff A, Jollife G, Langer R, Williamson
E editors. American Herbal Pharmacopoeia: Botanical Pharmacognosy. Microscopic Characterization of Botanical medicine. Boca Raton: Taylor \& Francis, CRS press; 2011.p.274.

26. Wallis TE. A Text Book of Pharmacognosy. 3rd eds. London: J \& A Churchill; 1976.p.113.

27. Franco C. Relation between chromosome number and stomata in Coffee. Bot Gaz1939;100:817-27. https://doi.org/10.1086/334832.

28. Hickey LJ. Classification of the architecture of dicotyledeneous leaves. Am J Bot 1973;60:17-33. https://doi.org/10.2307/2441319.

29. Metcalfe CR, Chalk L. Anatomy of the Dicotyledons: Wood Structure and Conclusion of the General Introduction. 2nd ed. Vol 2.Great Britain:The Clarendon, Oxford; 1985

30. Sudhakaran MV. Botanical Pharmacognosy of Andrographis paniculata (Burm.f) Wall. Ex. Nees. Pharmacogn J. 2012;4(32):1-10. https://doi.org/10.5530/ pj.2012.32.1.

31. Sudhakaran MV. Botanical Pharmacognosy of Holostemmaada-kodien. Schult. Pharmacogn J. 2017;9(2):163-70. doi :10.5530/pj.2017.2.27.

32. Wagner GJ. Secreting glandular trichomes: more than just hairs. Plant Physol. 1991;96(3):675-9. https://www.ncbi.nlm.nih.gov/pmc/articles/PMC1080829/

33. Seago JL, Marsh LC, Stevens KJ, Soukup A, Votrubova O, Enstone DE. A re-examination of the root cortex in wetland flowering plants with respect to aerenchyma. Annals of Botany. 2005;96(4):565-79. doi:10.1093/aob/mci211.

34. Tiner RW. The concept of a hydrophyte for wet land identification: Individual plants adapt to wet environments. Bioscience. 1991;41(4):236-47. doi: https:// doi.org/ 10.2307/1311413.

\section{GRAPHICAL ABSTRACT}

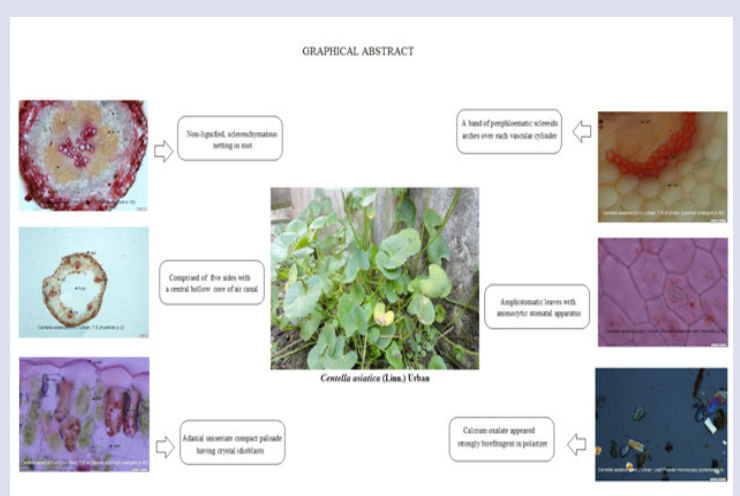

\section{SUMMARY}

- Centella asiatica (Linn.) Urban is a tropical medicinal plant, native to Southeast Asian countries. It is an important medicinal plant with rejuvenating properties, used in Ayurveda for promoting vitality and life.

- The plant is often considered as a 'panacea' for several human ailments and the biological actions often had been ascribed to its pentacyclic triterpene compounds, mainly asiatic acid, madecassic acid and triterpene saponin; asiaticoside, madecassoside. The plant is also a good source for several micronutrients, iron, phosphorus, sodium, vitamin C, vitamin A, carotene and dietary fibers.

- Actinodromous major venation, animocytic stomata, distinctive contour of midrib and petiole, crystals in idioblasts, arenchyma lacunae, sclerenchymatous netting, periphloematic sclereids are remarkable features diagnostic of the taxon

- The anatomical markers, quantitative microscopic characteristics were delineated from the stem, root, stolon and leaves of Centella asiatica may provide useful information for regulatory aspects of quality control measures of the crude drug materials.

\section{AUTHOR PROFILE}

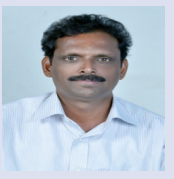

Madathilparambil Vasu Sudhakaran (M.V.Sudhakaran): Has received the Ph.D Degree of the University of Kerala. Currently he is positioned as Associate Professor, UGC-Academic Staff College of the University of Calicut. He is a research guide in Botany under the faculty of Science. His research interests include genetic diversity analysis, genetic effects of inbreeding, and the pharmacognostical and phytochemical aspects of medicinal plants.

Cite this article : Sudhakaran MV. Botanical Pharmacognosy of Centella asiatica (Linn.)Urban. Pharmacog J. 2017;9(4):546-58 